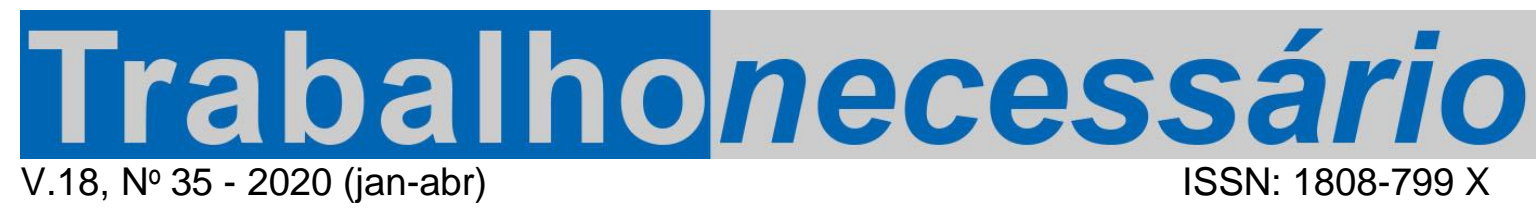

DOI: https://doi.org/10.22409/tn.v18i35.40516

\title{
BREVES CARTAS A UMA JOVEM PROFESSORA, ALGUNS POEMAS E OUTROS RELATOS - ANA LÚCIA ESPÍNDOLA (IN MEMORIAN) ${ }^{1}$
}

Apresentação de Léa de Lourdes Calvão da Silva²

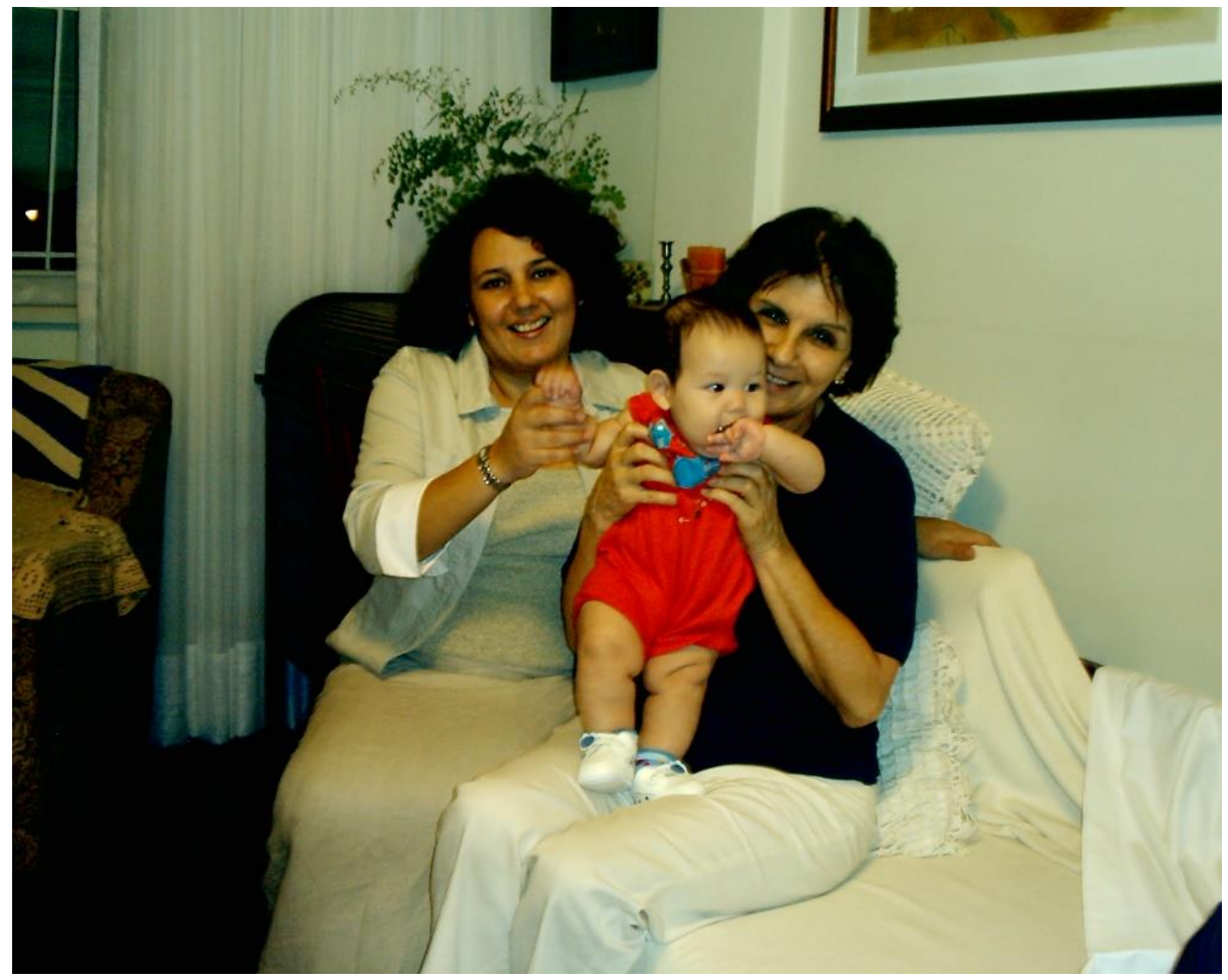

\footnotetext{
${ }_{1}^{1}$ Memorial recebido em 15/09/2019. Aprovado em 04/10/2019. Publicado em 23/01/2020.

2 Doutora em Educação pela UNICAMP (Campinas-SP, 1999), mestrado em Educação pela Universidade Federal do Rio de Janeiro (RJ, 1981) hoje aposentada, foi professora na Faculdade de Filosofia Santa Dorotéia, em Nova Friburgo/RJ, na Universidade Federal de Mato Grosso do Sul, em Campo Grande/MS e na Universidade Federal Fluminense, em Niterói/RJ. Membro do Neddate-FE/UFF e do Comitê Científico da TN - Trabalho Necessário, tem experiência na área de Educação, com ênfase em Trabalho e Educação, atuando principalmente nos seguintes temas: trabalho e educação, trabalho infantil, e educação e patrimônio cultural. E-mail: leacalvao@uol.com.br
} 


\title{
Apresentação
}

\begin{abstract}
Sei que andei mil e quinhentos quilômetros e quarenta e dois anos para encontrar o grupo de jovens que, de professora, me fez mais aprendiz. Eram estudantes do Curso de Pedagogia da Universidade Federal do Mato Grosso do Sul, campus de Campo Grande. Talvez até sem perceber, ensinaram-me o que a eles me uniria por todos os nossos anos de convivência e por todos os depois: a força daquela terra vermelha, os conflitos das fronteiras agrícolas e das terras indígenas, o desenho de sua cidade solar, a busca incansável pelo saber, a arte da solidariedade, das formas de amor ao outro, da luta contra as injustiças sociais (Calvão, 2019).
\end{abstract}

Ao apresentar o memorial de Ana Lúcia Espíndola - Breves cartas a uma jovem professora, alguns poemas e outros relatos - como parte da defesa para progressão de Professora Titular da Faculdade de Educação da Universidade Federal do Mato Grosso do Sul, preciso começar com esse depoimento porque ela, pessoa de compartilhamentos, ali criou e reforçou espaços para inesgotáveis perguntas e para a busca de caminhos de conhecimentos que falassem do mundo e de nossas possibilidades de nele interferir.

Eram os anos de 1980 e Ana Lúcia era quase uma menina. Dezessete anos de idade, de pronto desenganava quem a supusesse frágil: ainda criança, já se definira corajosa guerreira a favor da vida e, já então, entendera ser a educação a forma de luta que escolheria cumprir. Essa luta, da qual jamais desistiu, está registrada, em palavras da ciência e da arte, no memorial apresentado à academia para sua promoção a professora titular. Ana Lúcia amava as palavras escritas e faladas, sua musicalidade, seus contornos, seus segredos. Gostava de descobrir o que elas, as palavras, enunciavam ou denunciavam, por isso, leu o tanto que pôde, escreveu pequenos contos, divulgou entre amigos alguns escritos do seu filho, feliz por ser ele também um grande leitor. Foi uma pessoa da palavra.

Seu memorial, de palavras de rigor e poesia feito, é uma aula de sensibilidade, de dedicação ao trabalho, de coragem política e compromisso ético com a educação da classe trabalhadora e da escola pública referenciada nos interesses dessa classe.

Com sua publicação, a revista Trabalho Necessário oportuniza-nos acompanhar o trabalho de uma professora visceralmente comprometida com os interesses da classe trabalhadora. Permite-nos refletir sobre 0 trabalho silencioso de professores e professoras das nossas escolas públicas, carentes 
de estímulos e de apreço e que, todavia, continuam sua luta política, promovendo a construção do conhecimento e as indagações sobre a realidade. Como Ana Lúcia, esses professores e essas professoras sabem que se a educação não resolve, sozinha, os problemas sociais, ela é indispensável à sua compreensão. De acesso e frequência obrigatória, a escola pública é o lugar de educação formal de que dispõe a classe trabalhadora. Ali, ao dominar estudos de ciência, filosofia e arte, terão instrumentos para compreender a realidade social e pensar formas de transformá-la a favor de suas necessidades.

Essas lições aprendidas de Ana Lúcia são uma boniteza, palavra de que ela gostava tanto, e nos consolam de sua partida tão precoce. Ela partiu no último maio, aos 53 anos, mas sua presença continua nos textos que escreveu, nos sorrisos que nos deu, em Leon, que ela amou infinitamente (outra de suas palavras queridas), nos exemplos de força e delicadeza que nos deixou, traços já impressos em seu nome: Ana é largueza, é amplidão; Lúcia é luz, é claridade. Sua presença continua na luta que com ela partilhamos: buscar e valorizar o conhecimento, lutar por uma sociedade igualitária e falar, sem medo, com o coração.

\section{O memorial como parte de defesa para professora titular da Faculdade de} Educação da UFMS ${ }^{3}$

\section{“A HISTÓRIA ANTES DA HISTÓRIA: BREVE INTRODUÇÃO}

Sempre por trás de uma história há muitas histórias. Por trás de cada trabalho realizado, há um filho que ficou só em casa sob os cuidados de terceiros, um marido ou uma esposa que precisou abrir mão da companhia para que o outro realizasse uma determinada atividade, um café ou um chope cancelado com um grupo de amigos, um almoço de domingo esquecido com a família. Por

\footnotetext{
${ }^{3}$ Ana Lúcia Espindola (In memorian). Graduação em Pedagogia (Séries Iniciais) Licenciatura Plena pela Universidade Federal de Mato Grosso do Sul (1988), mestrado em educação pela Universidade Federal de São Carlos (1998) e doutorado em educação pela Universidade de São Paulo (2003). Realizou doutorado sanduíche na Universidade de Paris VIII, França, sob a orientação do Professor Doutor Bernard Charlot. Professora Associada da Universidade Federal de Mato Grosso do Sul, desde 1992, vinculada ao Programa de Pós-Graduação em Educação Social e ao Doutorado em Letras na UFMS.
} 
isso, ao precisar, aqui, relatar minhas atividades profissionais dos últimos oito anos com o objetivo de concorrer ao posto de professora titular na Universidade Federal de Mato Grosso do Sul, percebo o quanto a história dessa trajetória é entrelaçada à da minha vida pessoal como mãe, filha, militante, amiga e tantos outros papéis que precisamos desempenhar diuturnamente em nossas vidas. Percebo também que, tal como na música de Milton Nascimento e Fernando Brant, "Há um passado no meu presente", em muitos momentos sou guiada por esse passado.

Assim, organizo este memorial em dois formatos, procurando dar conta dos diferentes papéis e tempos que, ao contar minha trajetória profissional, se entrecruzam. Fiz uma opção por abrir alguns dos itens com uma breve carta dirigida a uma jovem professora (em que, por vezes, o tom de informalidade deixa escapar materialidades linguísticas que alguns insistiriam em corrigir...). Pode parecer um tanto pretensioso alguém achar que tem algo a ensinar a um profissional que está começando, mas não são conselhos no sentido de uma voz superior falando a uma voz inferior, e sim vozes que, em relações horizontalizadas, expressam angústias e esperanças que se pretende dividir.

Quem é a jovem professora a quem me dirijo? São as tantas ex-alunas que tive nesses 34 anos de magistério, dos quais os últimos 26 foram no curso de Pedagogia da UFMS de Três Lagoas. São as muitas colegas de trabalho a quem acolhi e por quem fui acolhida nesses anos todos e que, em alguns casos, e apesar das diferenças etárias, vieram a se tornar minhas grandes amigas. E, certamente, é também a mim mesma, que me tornei professora aos 18 anos na escola básica e aos 26 na universidade e que teria gostado, naquele tempo, de ter ouvido alguns conselhos de alguém com uma experiência mais alargada que a minha. Talvez me tivesse poupado sofrimentos desnecessários. Talvez.

Dirijo-me sempre às jovens professoras, embora entenda e defenda 0 espaço educativo como um lugar que também deve estar contemplado com a presença masculina desde a Educação Infantil. Mas fiz a opção de me dirigir às mulheres porque é delas que sei. Sei o que é viver dividida entre os afetos e as obrigações. O que é cuidar de filho, de casa, dos pais, dos irmãos e, ainda assim, arrumar tempo para buscar ser uma boa profissional. Sei o que é andar em cordas bambas buscando equilíbrios nem sempre possíveis. E isso é uma 
realidade constante para todas as mulheres com quem falo e divido minha vida. Portanto, por saber delas e por ser uma delas, é a elas a quem me dirijo.

Escolhi inserir em partes do memorial o gênero epistolar porque sou assumidamente saudosista. Tenho saudades de escrever e de receber cartas. É um gênero claramente intimista e que já foi classificado por Cícero como "diálogos entre ausentes" ou ainda, por Poliziano e Tasso, como "metade de um diálogo" (MUHANA, 2000, p. 1). Certamente é o gênero que melhor se encaixa na já mencionada perspectiva que pretendo adotar aqui: a de uma conversa horizontalizada entre amigos.

Peço desculpas antecipadas por dois problemas identificados. O primeiro é o tom por vezes panfletário do meu texto. Não pude evitar. Fui - e continuo sendo -, acima de tudo, uma militante. É isso que sou e, tendo em vista a possibilidade de um texto menos preso às normas acadêmicas, me dei o direito de que isso aparecesse. Outro ponto, e que talvez seja complementar a esse, é o fato de que muitas vezes me pego caindo em clichês. Sei disso, mas também sei que um texto só é clichê para quem já domina aquele gênero e as coisas que ali estão. Então, tenho a esperança de que, mesmo as coisas muito simples que digo aqui, para algumas pessoas realmente serão novas. Para o leitor imaginário que construí com base no que disse no início deste texto, talvez haja aqui coisas novas e importantes.

\section{PROCESSOS FORMATIVOS EM DIFERENTES INSTÂNCIAS}

\subsection{Forme-se, professora, forme-se! (Carta número 1)}

\section{Querida amiga:}

Me dirijo a você nesta carta para lhe dizer que sei o quanto o processo formativo pode ser doloroso e dar a sensação de nos roubar o tempo. O tempo, que, como nos ensinou Antônio Cândido, é o tecido da nossa vida e que muitas vezes gostaríamos de dedicar aos que amamos, às levezas da vida a que todos têm (ou deveriam ter) direito, às amenidades. Entretanto, estamos nós, em uma tarde de domingo ou numa noite de sábado, envoltas em teses, dissertações, artigos, livros, escrevendo e reescrevendo coisas, tentando ampliar nosso universo de conhecimentos sobre tantas coisas que antes nem sabiamos que existiam. Pois bem, assim como você, eu também, em muitos momentos, senti isso. É, minha amiga, formar-se nem sempre é agradável. Aprendi com uma professora da graduação (Léa de Lourdes Calvão, sobre quem falarei mais detalhadamente em outra carta) que estudar não precisa ser uma coisa necessariamente chata, mas, certamente, também não é um eterno domingo de férias. Repeti isso para mim mesma em todos os finais de semana, feriados e dias 
ensolarados em que, enquanto os outros podiam ir ao cinema, à praia, ou simplesmente ver tv largados no sofá, eu precisava estudar. Mas, devo dizer, nunca me arrependi do tempo dedicado a isso. Para aqueles que, como eu, vêm das camadas populares, a única forma de alcançar a tal cultura mais elaborada é assim. Estudar infinitamente. Portanto, estude sim, estude muito. Leia todos os livros e teses que lhe parecerem necessários (porque certamente serão). E, se você, como eu, trabal ha pela construção de novas relações sociais, pense sempre em Paulo Freire, com seu ensinamento que, para mim, foi de grande valia: "Estudar é um dever revolucionário". Estudemos, então, inclusive para fazer a revolução e mudar as relações sociais.

Entretanto, minha querida, não se esqueça de que podemos nos formar em muitas outras instâncias. Quando fui fazer doutorado e me mudei para São Paulo, minha orientadora (Zilma de Oliveira), em nosso primeiro encontro, vendo minha ansiedade, me disse: "Fazer doutorado é também viver a cidade com tudo que ela te proporciona. Então, faça as disciplinas, trabalhe na tese, mas também vá ao cinema, ao teatro, aos museus, aos shows aos quais puder $i^{\prime \prime}$. Foi um grande conselho e repasso agora a você. Veja muitos filmes, porque poderá aprender muitas coisas em uma sala de cinema. Vá aos museus todos que conseguir, porque a arte nos humaniza de um jeito que não dá para descrever. Ver, ao vivo, uma obra de arte que você viu a vida inteira em livros é algo que marca a existência de qualquer um. Veja pelo menos um show do seu músico favorito. Viaje para todos os lugares que puder e, quando for a esses lugares, busque saber sua história e tente ver coisas que ninguém viu. E, sempre que possível, leia literatura. No intervalo entre um capítulo e outro da tese que escreve, enquanto caminha na esteira, na fila do banco ou no supermercado. Nunca se afaste da literatura. Nem nos momentos de maior aflição com o tempo. O que aprendemos com a literatura não é só sobre o mundo; é sobre nós. Sobre o que Ana Maria Machado diz em Bisa Bia, Bisa Bel: "sobre nossas encruzilhadas escondidas". E essas, vale a pena serem conhecidas.

Bem, querida amiga, é isso. Forme-se. Sempre, com livros, com cinema, com literatura e com a vida mesmo.

Para terminar, deixo para você um belíssimo poema de Adélia Prado que, de certa forma, nos fala disso:

Ensinamento

Minha mãe achava estudo a coisa mais fina do mundo. Não é.

A coisa mais fina do mundo é o sentimento.

Aquele dia de noite, o pai fazendo serão, ela falou

comigo:

"Coitado, até essa hora no serviço pesado".

Arrumou pão e café, deixou tacho no fogo com água quente.

Não me falou em amor.

Essa palavra de luxo.

Com amor, essa palavra de luxo,

Ana.

1.2 Processos de formação e longevidade escolar: planejamentos e acasos

\author{
O processo de escolarização das crianças oriundas das camadas \\ populares é marcado por algumas características, dentre elas as interrupções e
}


a não linearidade (ZAGO, 2008), e, ao mesmo tempo, por um trabalho escolar desenvolvido pelas famílias para garantir aos filhos uma escolarização de longa duração nem sempre reconhecido pela escola (VIANA, 2008). Em relação ao que as pesquisas sobre o processo de escolarização em meios populares têm apontado, o meu caso difere de alguns, em certos aspectos, e assemelha-se a outros.

Tenho clareza de que o que garantiu meu futuro de mulher adulta escolarizada foi o fato de ter sido identificada pela minha família como aquela filha em quem era possível depositar as esperanças de sucesso escolar, tal como apontado por Bourdieu e seus seguidores (NOGUEIRA, 2002).

Sou a caçula de uma família com baixo capital cultural e escolar e composta por seis irmãos. Meus pais foram trabalhadores rurais com pouca e nenhuma escolarização: meu pai frequentou a escola por aproximadamente dois meses; minha mãe nunca foi à escola e é, portanto, analfabeta. Meus irmãos também não estudaram. Então, o que garantiu a mim ser a filha "escolhida" que receberia todos os investimentos familiares para que pudesse ter longevidade escolar? Em minha avaliação, isso se deu basicamente pelo fato de que aprendi a ler de forma pouco convencional, já contada por mim em muitas ocasiões.

Morei com meus pais na zona rural de Mato Grosso do Sul até os oito anos. Minhas irmãs mais velhas me ensinaram as letras do alfabeto e as diversas combinações entre elas. Vivíamos entre o campo e a cidade: havia temporadas em que morávamos nas periferias de Campo Grande e, em outras, nas fazendas onde meus pais trabalhavam em diferentes ocupações. Após aprender 0 alfabeto, passava grande parte do tempo repetindo e pedindo explicações a todos os adultos que me rodeavam. Posteriormente, fomos para uma fazenda sem minhas irmãs, que eram as minhas maiores "informantes" sobre o sistema de escrita que tentava compreender. Para a fazenda, fomos apenas eu, meus pais e meu irmão, que era seis anos mais velho que eu. Falo de meu irmão porque ele teve, sem saber, participação fundamental nesse processo. Ele era um grande leitor de revistas em quadrinhos e levou com ele, para a fazenda, uma caixa de papelão cheia dessas revistas. Eu, com a posse do novo conhecimento que havia adquirido, passava o dia juntando as letras e tentando ler. Não me lembro muito bem do processo. Mas me lembro do dia em que me descobri leitora. A chegada de uma carta de Campo Grande e a impossibilidade de minha 
mãe lê-la levaram-me a pedir para olhar o envelope, pois, dizia eu, reconheceria a letra de quem havia escrito. Para grande surpresa de todos, e, acho, especialmente minha, li todo o texto. Li como se soubesse ler desde sempre. Isso gerou nos meus pais imensa surpresa e começaram a manifestar o desejo de que voltássemos para a cidade para que eu pudesse, finalmente, frequentar a escola.

Voltamos para a cidade, mas, no caminho da escolarização das camadas populares, há sempre percalços. Enfrentávamos, em todo o país e, especialmente, em Mato Grosso do Sul, um enorme déficit de vagas escolares. Não havia vagas nas escolas públicas. Lembro, e já contei em minha tese de doutorado, de minha mãe indo comigo pela mão, de escola em escola, e recebendo sempre a negativa em relação à possibilidade de acolhimento. Com muito sacrifício financeiro, minha mãe decidiu matricular-me em uma sala multisseriada que funcionava na própria casa da professora e que os pais pagavam para ter os filhos estudando. Não devia ser tão caro, mas, para nós, representava sacrifícios. Minha mãe juntava moedas em um cofre e, muitas vezes, minha mensalidade foi paga assim. A professora, sabiamente, ao perceber que eu lia com fluência e por eu já ter oito anos, matriculou-me diretamente na segunda série. Iniciei assim minha vida escolar pulando uma etapa, aquela destinada ao processo de alfabetização.

Meu percurso escolar foi sem rupturas. Nunca reprovei nem nunca abandonei a escola. Esse não é o percurso comum de crianças com a mesma origem que a minha. Segundo pesquisas desenvolvidas por Zago (2008), nas camadas populares os percursos são acidentados, com inúmeras rupturas, abandonos e recomeços. No meu caso, nunca me imaginei - nem por um momento - longe da escola. Mesmo quando não me senti acolhida ou quando não reconheci aquele espaço como meu, nem assim pensei em sair dali. Acho que fiz de forma satisfatória a conversão apontada por Lahire (1993): aquela realizada pelas crianças das camadas populares em direção ao aprendizado escolar.

Fui sempre uma boa aluna. A partir do Ensino Médio - que iniciei aos 15 anos -, precisei conjugar trabalho e escola. Fui o que, na sociologia, se chama de estudante trabalhador (ROMANELLI, 2008): não bancava a casa com meu salário, mas ele era importante no conjunto dos rendimentos da família. 
Cursar o Ensino Médio foi, para mim, um dos primeiros desafios enfrentados, mas não apenas por me iniciar no mundo do trabalho conjuntamente. Fui fazer o magistério em uma escola localizada no centro de Campo Grande com uma ótima reputação. Meu pai precisou, já naquela época, dormir na fila para conseguir uma matrícula no curso noturno. Entretanto, morávamos em um bairro muito afastado e com pouca urbanização: não havia luz elétrica, rede de esgoto e o transporte público era precário. Havia três horários de ônibus por dia, e o último saía do centro de Campo Grande às 19 horas, horário em que eu estava iniciando a jornada escolar. Foi preciso muito esforço e alguns arranjos familiares para que eu pudesse frequentar o ensino médio e não fizesse parte das estatísticas de abandono, tão fortes nesse nível de ensino. Por algum tempo, enquanto fazia apenas trabalhos informais, eu dormia na casa de uma das minhas irmãs, que morava num bairro com circulação de ônibus. Depois, quando iniciei um trabalho formal, com carteira registrada, um dos meus irmãos, que também morava com meus pais e tinha uma moto, esperava-me todos os dias até o término do horário da aula para me levar para casa. Essas são as práticas invisíveis de que sempre me lembro quando discuto a escolarização nas famílias de camadas populares. O esforço de todo um grupo (pais, irmãos, primos, tios) para que um dos membros da família estude. $\mathrm{Na}$ maior parte das vezes, essas práticas não são vistas nem reconhecidas pela escola.

O ingresso na universidade, aos 18 anos, no curso de Pedagogia, foi algo que me marcou de forma definitiva. Foi lá que comecei a compreender o meu lugar, minha condição e as possibilidades que tinha. Pelas coisas que comecei a aprender, pela forma como passei a ver o mundo e, especialmente, pelo contato com pessoas que iriam mudar minha história, a universidade me transformou. Um grupo de amigos jovens, rebeldes, livres e sonhadores como eu e uma professora que, na minha trajetória, fez toda a diferença para que eu estudasse e entendesse 0 mundo numa perspectiva transformadora foram os elementos que me conduziram a uma nova compreensão e a começar, ainda sem saber, uma nova história. O grupo de amigos foi aquele com quem militei no movimento estudantil e sindical e no Partido dos Trabalhadores. A professora foi a de Sociologia da Educação, que marcou minha vida da forma mais linda e 
doce que um professor pode marcar a vida de um aluno. Preciso falar dela porque parte do que sou vem dela, Léa de Lourdes Calvão.

Léa foi nossa professora de Sociologia no segundo semestre do curso. Confesso que, até conhecê-la, eu vivia uma rebeldia um tanto inconsequente. Uma das coisas que pensava era que eu, tendo que trabalhar o dia todo, não tinha obrigação de estudar como os outros. Como era medianamente inteligente, passei o primeiro semestre com boas notas, mas pouca dedicação. Léa, em suas aulas, nos ensinou sobre o compromisso que precisávamos ter com a escola pública e que esse compromisso passava, dentre outras coisas, por uma boa formação. Ensinou-nos que o acesso ao conhecimento não era uma obrigação, mas um direito. Ela passou a ser a referência para aquele grupo de jovens pobres, vindos das periferias da cidade e com histórias muito parecidas. Mostrava-nos um mundo além do que conhecíamos: levava-nos ao cinema e falava-nos sobre cinema de arte, sobre música erudita, sobre artes plásticas, sobre literatura. Tudo que para nós era distante e chato tornava-se, nas aulas dela, atraente. Ela sabia como fazer a ponte entre o nosso mundo e aquele que nos queria mostrar. A mim, particularmente, foi a maior influência que recebi. Até conhecê-la, eu nunca havia estado em uma casa que tivesse uma biblioteca. $E$ ela não apenas me mostrou sua biblioteca como me ofereceu acesso a todos aqueles livros.

Passei assim os quatro anos no curso de Pedagogia, reconstruindo minha visão de mundo e preparando-me para ser melhor no ofício que já exercia: professora das séries iniciais.

Logo após ter concluído o curso de Pedagogia, houve a criação do mestrado em Educação na UFMS. Embora alguns dos meus ex-professores me perguntassem por que eu não tentava a seleção, secretamente eu achava que aquilo não era para mim. Aqui percebo uma forte semelhança entre minha escolarização e aquelas estudadas pelas pesquisas sobre as camadas populares. Não houve interrupções em minha jornada escolar até a conclusão do ensino superior, mas também não houve um planejamento. A minha ida para o mestrado, por exemplo, foi muito mais fruto do acaso do que de um planejamento minimamente desenhado. As primeiras turmas foram compostas pelas pessoas que eu mais admirava no cenário educacional de Campo Grande, e eu pensava sempre que fazer mestrado era para eles, não para mim. Além 
disso, havia uma questão muito pragmática: eu trabalhava dois períodos e meu salário era fundamental para contribuir com as despesas da minha família. Não podia abrir mão de um período para estudar. Novamente Léa teve um papel importante nisso. Ao reclamar a ela um dia sobre o fato de que não conseguiria nunca fazer mestrado, ela, de uma forma firme e amorosa como sempre fazia, me disse que eu deveria sim tentar, mesmo tendo que me esforçar e trabalhar o dobro do que os outros.

Entretanto, a possibilidade de seguir estudando só foi possível após fazer um concurso para professora na UFMS em 1992. Vivi uma enorme angústia sobre fazer ou não o concurso, pois achava incoerente o fato de, como aluna, ter defendido sempre que os professores da universidade deveriam ter no mínimo mestrado e, depois, fazer um concurso que exigia apenas graduação. Uma amiga convenceu-me de que não havia incoerência, tendo em vista que o concurso já estava aberto para portadores de diploma de graduação. Se houvesse alguém com maior titulação, certamente seria aprovado.

Ingressei na UFMS em novembro de 1992 e, no final de 1993, comecei a fazer a seleção para o mestrado. Resolvi fazer primeiro na UFSCar, apenas para saber como seria um processo seletivo. Pensava em fazer em Campo Grande, já que não acreditava na possibilidade de ser aprovada em São Carlos. Entretanto, contrariando minhas expectativas, fui aprovada. E aí começou um novo dilema. Não tinha ainda direito a ter afastamento para estudos, portanto, precisaria fazer o mestrado viajando semanalmente para São Carlos, que fica a 500 km de Três Lagoas. Não havia ônibus direto; era preciso fazer uma baldeação de ônibus numa cidade vizinha. Saía de Três Lagoas na segunda, às 15 horas, e chegava a São Carlos às 3 da manhã. Assistia às aulas terça, quarta e quinta e, na quinta à noite, voltava para Três Lagoas, onde ministrava aula sexta à tarde e à noite. Muita gente achava que eu não daria conta, inclusive eu. Mas quase tudo deu certo.

Logo que vim para Três Lagoas, casei-me com Pedro, que havia conhecido ainda em Campo Grande. Ao final do curso de mestrado, logo após minha qualificação, ele adoeceu. Começou um novo desafio. Pedro foi diagnosticado com um câncer no pulmão em estado já avançado, inclusive com metástase em vários órgãos. Fomos a Campo Grande para fazer o tratamento e permanecemos lá pelos próximos seis meses. Nesse período, eu ainda tentava 
fazer as correções necessárias e sugeridas pela banca de qualificação. Cheguei a pedir uma autorização ao diretor do hospital onde ficávamos para instalar um computador no apartamento que ocupávamos. Numa das minhas idas a Três Lagoas, contei isso à professora mais antiga no curso e ela me deu um conselho extremamente sábio. Ela me disse que era bíblico o fato de que há tempo para tudo e que "agora" era meu tempo de cuidar do Pedro. Ter ouvido isso de uma professora mais experiente (professora Lucrécia Stringhetta Mello, com quem trabalhei por 20 anos dos 26 que estou na UFMS) foi fundamental para eu entender o processo que vivia. Acreditava fortemente - contrariando todas as expectativas médicas - que Pedro iria superar a doença, mas, nesse dia, no corredor do CPTL, ouvindo a professora, percebi que isso poderia não acontecer. Abandonei a dissertação e dediquei-me exclusivamente à tarefa de cuidar dele até sua morte, seis meses depois, em julho de 1997.

Retomei a dissertação e, em março de 1998, consegui defender, ainda sob o impacto da dor e da perda que me assolavam.

Trabalhei na dissertação de mestrado com uma temática que dava continuidade ao trabalho que desenvolvia antes de ser professora da UFMS, a alfabetização. Fui professora alfabetizadora na rede estadual de Campo Grande por oito anos.

Ao final de 1998, comecei o processo de seleção de doutorado e fui aprovada em duas grandes instituições, USP e Unicamp. Fiz a opção pela USP e fui ser orientanda de Zilma de Moraes Ramos Oliveira, com uma temática que dava continuidade ao que já havia estudado no mestrado, mas agora com um interesse mais específico: a questão da leitura.

O doutorado foi um período de muita tranquilidade e ventos brandos se comparado à turbulência que havia sido o mestrado. Consegui afastamento integral das minhas atividades didáticas e mudei-me para São Paulo para realmente viver a universidade e aproveitar ao máximo o tempo que, desde o final do ensino fundamental, eu nunca mais havia tido para estudar. Óbvio que não consegui ler nem a metade das coisas que planejei (literatura especialmente) nem fazer todos os cursos com que sonhei, mas ainda assim foi um período de acerto de contas com a minha formação.

Iniciei o doutorado em 1999. Em relação ao mestrado que havia feito, o curso da USP era muito tranquilo e com poucas exigências de disciplinas 
obrigatórias, o que me permitiu fazer quatro disciplinas apenas. Logo na primeira conversa com minha orientadora, ela me perguntou sobre minha disponibilidade em fazer um doutorado sanduíche. Fiquei completamente encantada com a proposta, mas, novamente, duvidei de que aquilo realmente fosse para mim. Não sabia uma língua estrangeira, nunca havia saído do país, não tinha ideia de como o processo funcionava, mas, obviamente, queria.

Comecei então a trabalhar na perspectiva do doutorado sanduíche tomando a decisão de aprender francês, tendo em vista que tinha muito interesse no que era produzido sobre leitura pelos estudiosos franceses. Além disso, comecei também a fazer um curso de inglês, pois muitas das leituras pedidas no doutorado eram nessas duas línguas. Isso produzia em mim um efeito contraditório: por um lado, sentia-me estrangeira naquele lugar, com a completa sensação de inadequação àquele espaço; por outro, entendia que era um desafio que precisava superar.

Novamente, minha formação no doutoramento se deu com um pouco de acaso. Em 2000, enquanto eu e minha orientadora tentávamos conseguir os contatos dos pesquisadores franceses com os quais eu gostaria de trabalhar no estágio sanduíche, veio ao Brasil o professor Bernard Charlot para uma palestra em São Paulo. Zilma, minha orientadora, disse-me que ele trabalhava com uma temática com a qual eu certamente me identificaria e perguntou se eu não teria interesse em assistir a sua conferência e talvez conversar com ele sobre a possibilidade de ele me receber. Saí atrás de todas as obras dele disponíveis no Brasil e, quando comecei a ler, senti que era exatamente o caminho que gostaria de seguir com meu trabalho. As questões levantadas e investigadas por Bernard Charlot, em muito respondiam a minhas indagações e angústias naquele momento. Fomos então ouvir sua fala em São Paulo e Zilma nos apresentou. Ele foi completamente receptivo à ideia e saí da conferência já com uma carta de aceite para formalizar os papéis e ir a Paris para um estágio de seis meses. Andei pelas ruas de São Paulo apertando a pasta com a tão esperada carta de aceite ao peito, com alguma dramaticidade e muita alegria. Pensava: Como alguém sai da zona rural do interior do Brasil e vai parar em Paris? No meu caso, só pela via escolar mesmo.

Em Paris, continuei estudando francês e frequentei também um curso ministrado por Charlot e sua equipe na Universidade de Paris 8. Fiz um 
planejamento rigoroso, que me permitiu viver um pouco do que a cidade oferecia, sem, no entanto, deixar de cuidar da tese. Estudava francês três vezes na semana e trabalhava em casa o restante do período. Às terças-feiras, saía para as bibliotecas e livrarias buscando as referências. De sexta, após o almoço, até o final do domingo, vivia a cidade. Voltei com mais de cem páginas escritas, falando francês com bastante fluência e com muitas referências novas aprendidas. Encontrei-me com Bernard Charlot uma vez ao mês durante os seis em que estive lá e ele contribuiu muito para a análise dos meus dados bem como com a inclusão de novas referências ao trabalho.

No início de 2003, em março, realizei minha defesa e recebi o título de doutora em educação pela Universidade de São Paulo. Durante o doutorado, duas coisas marcantes aconteceram em minha vida. A primeira delas foi ter-me casado novamente; a segunda, certamente o fato que mudaria minha perspectiva de mundo e tudo que havia vivido até então: no dia seguinte à entrega da tese para a defesa, descobri que estava grávida. Uma gravidez planejada, pensada e desejada. O acontecimento mais marcante e a experiência mais intensa que vivo até hoje, 15 anos depois, com o mesmo encantamento: a maternidade.

Retomei minhas atividades docentes grávida e trabalhei até a sexta-feira que antecedeu o nascimento do meu filho, que aconteceu numa madrugada de domingo. Talvez tenha sido o período em que mais trabalhei na vida. Sentia, de uma forma um tanto confusa, que precisava retribuir todo o investimento que a universidade havia feito em minha formação.

Fiquei nove anos entre o final do doutoramento e a decisão de fazer um estágio pós-doutoral. Como esse estágio já acontece no período que deverei circunstanciar neste Memorial, deixarei para falar dele como uma das atividades desenvolvidas entre os anos de 2011 e 2018.

1.3 Milite, professora, milite! (Carta número 2)

\section{Querida amiga:}

Te escrevo em tempos duros. Tempos que trazem de volta temas e problemas que a minha geração achou que estivessem superados. Veja só que ingenuidade. Como que nós, que fomos às ruas nos grandes movimentos de massa dos anos de 1980, poderíamos supor que estaríamos, nesses quase anos 20 do século XXI, tendo que defender direitos básicos de participação e, ainda, conversar e convencer as pessoas de que a ditadura militar existiu e foi 
nefasta, de que a tortura é uma prática hedionda e que não pode ser defendida sob nenhum ponto de vista, de que a nossa ainda jovem e frágil democracia precisa ser mantida? Sim, cara amiga, estamos vivendo tempos muito duros. Lembro aqui que Antônio Cândido, em seu belíssimo texto "O direito à literatura", nos dava uma maravilhosa lição de otimismo ao acreditar que, na nossa época, o mal, embora continuasse sendo praticado, não estava mais sendo proclamado, e isso, avaliava o autor, era uma prova de que o homem não mais o acharia natural. Isso representaria, certamente, um avanço. O texto foi escrito em meados dos anos de 1980, e a impressão que tenho é que, desde então, retrocedemos. O mal volta a ser proclamado e, portanto, se acha natural que seja assim. As práticas racistas, misóginas, homofóbicas que combatemos durante tantas décadas ganham lugar nos discursos e nas ações desenvolvidas pelo cidadão comum. A impressão que tenho é de que achávamos que caminhávamos rumo à social democracia europeia, erramos o caminho e fomos parar na Alemanha dos anos de 1930/1940. Isso é, no mínimo, desolador.

Por isso, mais do que nunca, nossa militância é necessăria. Quando falo em militância, não estou falando apenas da vinculação a um partido político (embora, conforme apontou Lenin, não haja revolução sem um partido revolucionário). Falo especialmente da militância em diversos fóruns que lutam por uma educação de qualidade, que tentam preservar direitos, tanto das crianças como dos professores, que buscam preservar a escola pública dos ataques que sofre hodiernamente.

Pode parecer clichê, porém tua presença numa reunião do sindicato, numa passeata, numa palestra organizada por um dos fóruns que discutem educação na tua cidade pode te ensinar muito e contribuir mais ainda para que entenda melhor tuas relações de trabalho e quem são os educadores nesse processo. O educador é educado nas contradições das lutas diárias. Há coisas que não aprendemos em nenhum outro lugar. E, se tua militância não servir para mais nada, saiba que serve, pelo menos, para consolar teus iguais e reverberar suas ideias. Aqueles que, de dentro desses espaços, sonham com novos tempos. Brecht:

E, para concluir, deixo a última parte de um poema antigo, mas tão atual, de Bertold

Aos que virão depois de nós

(...) Vocês, que vão emergir das ondas Em que

nós perecemos, pensem,

Quando falarem das nossas fraquezas,

Nos tempos sombrios

De que vocês tiveram a sorte de escapar.

Nós existíamos através da luta de classes,

Mudando mais seguidamente de países que de sapatos, desesperados!

Quando só havia injustiça e não havia revolta.

Nós sabemos:

O ódio contra a baixeza Também

endurece os rostos! A cólera

contra a injustiça Faz a voz ficar

rouca!

Infelizmente, nós,

Que queríamos preparar o caminho para a amizade, Não

pudemos ser, nós mesmos, bons amigos.

Mas vocês, quando chegar o tempo

Em que o homem seja amigo do homem,

Pensem em nós 
Com um pouco de compreensão.

Com todo meu carinho e o desejo de que também pense em nós com um pouco de compreensão, querida amiga.

Ana

\subsection{A militância como processo formativo}

A militância foi, para mim, uma das instâncias formativas fundamentais na minha trajetória docente e foi por meio dela que tive acesso, por exemplo, às discussões sobre o marxismo, quando, em 1984, fui "recrutada" para o PCB (Partido Comunista Brasileiro), que, naquele momento, ainda vivia na clandestinidade e se abrigava como uma das correntes do antigo PMDB (Partido do Movimento Democrático Brasileiro).

Enquanto cursava o Ensino Médio (antigo segundo grau), fui bastante seduzida pelo Movimento Estudantil Secundarista, especialmente pela corrente ligada à Convergência Socialista, um grupo Trotskista que compunha uma das diversas correntes internas do Partido dos Trabalhadores. Entretanto, dada a minha condição de estudante trabalhadora (trabalhava durante todo o dia, primeiro como secretária e posteriormente como ledora no Instituto para Cegos de Campo Grande, e fazia o curso noturno), minha participação foi sempre muito limitada no Movimento Estudantil.

Entretanto, ao iniciar a carreira docente, em abril de 1984, como professora contratada para substituir uma licença sindical de uma professora efetiva, comecei a viver realmente a militância. Uma semana após iniciar o trabalho na escola, extremamente feliz por ter conseguido um emprego de professora, foi anunciada uma grande greve da categoria. Os professores concursados da minha escola pararam as atividades, e os contratados, como eu, foram "orientados" (a melhor palavra seria "coagidos") a continuar com as atividades: não tínhamos nenhuma segurança, e a adesão à greve poderia significar nosso desligamento do quadro de professores. Fiquei, durante a primeira semana de greve, ministrando aulas com uma sensação muito forte de que essa não poderia ser a minha atitude. Vivi, pela primeira vez, a contradição de pensar algo e, por razões de sobrevivência, precisar fazer outra coisa.

Uma prática comum ao movimento sindical de professores era, durante as greves, formar comissões de piquete (que nunca foram piquetes no sentido 
exato do termo) para visitar as escolas que continuavam trabalhando e tentar convencer aqueles professores a aderir ao movimento. Logo na segunda semana de greve, recebemos essa comissão em nossa escola. Os professores da comissão não precisaram de grande esforço para me convencer da necessidade da adesão. Fui até o diretor, comuniquei minha decisão de aderir à greve, informei que sabia que poderia não ter o cargo de volta quando a greve acabasse, mas que não poderia continuar ministrando aula enquanto outros lutavam por mim. Sabia que aquela luta era minha também. Eu tinha 18 anos, precisava muito do emprego, mas sabia, ainda intuitivamente, que algumas decisões precisam ser tomadas cedo. Escolher nosso lado é fundamental. Escolhi o meu e tenho enorme orgulho de nunca ter me afastado dele. Fui para o sindicato, entrei na comissão de piquete e servi de exemplo para todas as professoras contratadas que usavam o argumento do contrato para não participar da greve.

Nessa primeira greve, aproximei-me de um grupo de professores que me deixava fascinada com as defesas de suas posições durante as assembleias e assim fui "recrutada" para o Partido Comunista do Brasil, iniciando, também, minha militância em partido político. Militei na célula de professores do PCB de 1984 até 1987, quando, por discordância da orientação dada pela direção do partido, me afastei.

Durante os oito anos em que fui professora na rede estadual de ensino em Mato Grosso do Sul, nunca saí do sindicato. Participei de todos os comandos das inúmeras greves que fizemos nesse tempo, inclusive de uma ocupação à governadoria do estado, que durou um mês pelo fato de estarmos com seis meses de salários atrasados.

Após meu desligamento do PCB, estreitei os laços com um grupo de amigos com quem convivia na universidade e que estavam também no movimento sindical. Esse grupo era, em sua maioria, composto por militantes do Partido dos Trabalhadores e, assim, fui, a partir de 1988, militar no PT, no grupo de professores. Formamos uma oposição cutista à direção do sindicato (tanto da ACP - Associação Campo-grandense de professores como da FETMS Federação Sul-mato-grossense de Trabalhadores em Educação) e concorremos a inúmeras eleições para a direção do sindicato. Não ganhamos eleição nesse período, mas sempre estivemos à frente do movimento. 
Quando passei no concurso da universidade em 1992 e assumi, em novembro, meus encargos didáticos em Três Lagoas, minha fama de sindicalista chegou antes de mim. Alguns esperavam uma professora radical e disposta a arrumar confusões; outros aguardavam a chegada de alguém que identificaram como mais uma companheira no sindicato docente, já naquele momento carente de quadros. Assim, logo que cheguei, fui enfaticamente convidada a fazer parte da nova diretoria da ADUFMS, seção sindical da Andes, Sindicato Nacional. A ADUFMS tinha uma estrutura que buscava atender a organização multicampi da UFMS. Então, havia uma direção central em Campo Grande e, na época, uma vice-presidência, um tesoureiro e um secretário para cada um dos campi do interior (Três Lagoas, Corumbá, Dourados e Aquidauana). Assumi a diretoria em Três Lagoas como vice-presidente e comecei a militância no movimento sindical universitário, bastante diferente do que eu conhecia no movimento sindical (MS) de onde vinha.

Participei de muitas greves na universidade, algumas como aluna e, a partir de 1992, como professora. Em todos esses movimentos, aprendi muito com os professores mais antigos, com os estudantes e com os dirigentes sindicais com quem convivi. Fui militante da ADUFMS até 2007, quando resolvemos, em Três Lagoas, criar uma sessão sindical ligada ao Andes Sindicato Nacional (Adleste), tendo em vista que a nova direção da ADUFMS havia feito a opção por vincular-se ao Pró-Ifes, movimento que surgiu após a greve de 1998 e que tentava dividir a base sindical do Andes.

Participei da direção da Adleste de 2007 a 2011 e voltei novamente para a direção em 2015, até a atual composição. Somos uma seção pequena, com uma média de 30 filiados, mas conseguimos, nesses anos todos, trazer temas importantes para o debate em Três Lagoas.

Em 1998, afastei-me definitivamente do Partido dos Trabalhadores e não tenho mais vinculação partidária como militante; apenas como simpatizante. De qualquer forma, descobri a minha trincheira nesses anos todos: o sindicato, com todas as contradições e problemas que é possível listar em relação à organização sindical no Brasil. Esse é, certamente, o meu lugar. 


\section{SER PROFESSOR: OFÍ́CIO EXERCIDO CEDO, ESCOLHA TARDIA.}

\subsection{Trabalhe, professora, trabalhe! (Carta número 3)}

Cara jovem amiga:

Trabalho nem sempre precisa ser sinônimo de tripalium, mas, algumas vezes, o é. Há momentos em que nos consome de tal forma, que parece que somos mesmo subsumidos por ele. O trabalho docente é particularmente capaz de fazer isso conosco. É um trabalho que sempre se prolonga para além da jornada contratada. São inúmeras atribuições didáticas que invadirão seu fim de semana, suas noites de descanso, suas madrugadas insones, suas férias. Não podemos - e nem estou sugerindo -, de forma alguma, naturalizar isso e precisamos sempre buscar que o tempo gasto em atividades que hoje não são pagas seja sim remunerado e, ao mesmo tempo, ter garantias do nosso tempo de lazer tão necessário.

Entretanto, é importante pensarmos numa coisa: nosso trabalho de professor precisa ter, além dos objetivos imediatos (que os alunos aprendam, que estejam interessados em nossas aulas, que se encantem com o conhecimento, que dominem determinados conteúdos) um sentido teleológico. Por que e para quem trabalhamos? O que desejamos como projeto de sociedade e de educação? Que tipo de homens e mulheres queremos formar? Para qual mundo? Ter essas perguntas e suas respostas como horizonte é o que nos dará, tenho cada dia mais certeza disso, a força para realizar o trabalho miudinho do dia a dia.

Muitas vezes você se sentirá vencida pelo cansaço do cotidiano, pelas atribulações da burocracia, pelo desrespeito que por vezes encontramos com nossa labuta. Mas, se você tiver um projeto para além do cotidiano, certamente isso irá lhe dar o ânimo necessário não apenas para realizar um bom trabal ho como também para lutar por melhores condições para que ele se realize. Há o que podemos fazer dentro dos muros da escola e o que devemos fazer além dos muros da escola.

O trabalho tem uma dimensão libertadora que precisamos buscar. Fazer bem nosso trabalho é, acima de tudo, um compromisso ético e político com nossos alunos, especialmente aqueles oriundos das camadas populares. Estes precisam sobremaneira de bons professores, de profissionais que estejam comprometidos em fazer com que o conhecimento produzido por todos seja também de acesso a todos e isso nem sempre é fácil. Ou melhor: isso nunca é făcil.

Digo a você, com toda honestidade: muitas vezes senti que estava sucumbindo. Ainda bem jovem, quando atuava na escola pública e dava mais aulas do que poderia aguentar, dizia: sei que o sistema quer mesmo que a gente desanime. Sei, mas não estou conseguindo lutar contra isso. Sentia um cansaço infindo. Mas, ao mesmo tempo em que pensava isso, não desistia do projeto de dar boas aulas. Nem do sindicato. Nem de estudar. E só não desistia porque pensava que o projeto de sociedade que eu havia sonhado precisava ser construído no hoje, precisava ser construído no presente. E acho que foi isso que me moveu nesses quase 35 anos de profissão. Sabemos que a educação não é, sozinha, capaz de transformar as relações sociais. Os pensadores ligados ao pensamento crítico-reprodutivistas iá nos ensinaram isso. Por outro lado, também aprendemos com o pensamento dialético que, se, de um lado, a escola tem força para reproduzir as relações sociais, ela também o tem para transformar. 0 espaço da escola é contraditório, e é exatamente nessas contradições que realizamos as mudanças. Parafraseando Paulo Freire, a escola não muda o mundo, mas o mundo também não mudará sem ela. E a mudança depende do nosso trabalho. Trabal ho que algumas vezes é quase de um operário reproduzindo movimentos repetitivos e, em outras, é de artista fazendo 
poesia ou pintando uma tela. Tanto um como outro, em algum momento, podem atingir as engrenagens necessárias para a mudança.

Deixo você novamente com Bertold Brecht e seu trabalhador que indaga:

\section{PERGUNTAS DE UM TRABALHADOR QUE LÊ}

Quem construiu a Tebas de sete portas?

Nos livros estão nomes de reis:

Arrastaram eles os blocos de pedra? E a

Babilônia várias vezes destruída Quem

a reconstruiu tantas vezes?

Em que casas da Lima dourada moravam os construtores?

Para onde foram os pedreiros, na noite em que a Muralha da China ficou pronta?

A grande Roma está cheia de arcos do triunfo:

Quem os ergueu?

Sobre quem triunfaram os Césares?

A decantada Bizâncio

Tinha somente palácios para os seus habitantes?

Mesmo na lendária Atlântida Os que

se afogavam gritaram por seus

escravos $\mathrm{Na}$ noite em que o mar a

tragou?

O jovem Alexandre conquistou a Índia.

Sozinho?

César bateu os gauleses.

Não levava sequer um cozinheiro?

Filipe da Espanha chorou, quando sua

Armada naufragou.

Ninguém mais chorou?

Frederico II venceu a Guerra dos Sete Anos.

Quem venceu além dele?

Cada página uma vitória.

Quem cozinhava o banquete?

A cada dez anos um grande Homem.

Quem pagava a conta?

Tantas histórias.

Tantas questões.

Ao trabalho então, jovem amiga, mas sempre com questões!

Com afeto, Ana 
2.2 O trabalho na escola pública como alfabetizadora

Ser professor, para mim, não foi necessariamente uma escolha. Como alguém vinda das camadas populares, com uma formação feita quase exclusivamente em escola pública e tendo que ser estudante trabalhadora, eu sabia que minhas opções eram poucas. Não foi por escolha que fui fazer magistério, aos 15 anos, e me tornei professora das séries iniciais aos 18 na rede estadual de ensino de Campo Grande. Posso dizer que, posteriormente, se transformou em uma escolha, mas, no princípio, foi o que via como possível para mim e como possibilidade de ter de forma rápida uma profissão.

Iniciei minhas atividades docentes como contratada em uma escola pública, em abril de 1984, após três meses de peregrinação na Agência Especial de Educação de Campo Grande (órgão que, à época, fazia o contrato dos professores). Já havia perdido as esperanças, tendo em vista o avançado do ano letivo quando fui convocada para substituir uma professora que havia se afastado para fazer parte da diretoria da Feprosul (hoje Fetems). Era um contrato de 22 horas para ser professora de ciências nas quartas séries da escola, tendo em vista que o currículo na rede era organizado por área de conhecimento. Trabalharia então com mais três professoras, cada uma responsável por uma área: Língua Portuguesa, Matemática, Estudos Sociais e Ciências.

Cheguei à escola José Barbosa Rodrigues, no Bairro Cidade Universitária, em Campo Grande, cheia de ânimo e projetos. Queria ser uma professora diferente, que marcasse de alguma forma a vida daquelas crianças. O que me faltava em formação para ser uma boa professora (eu tinha apenas o magistério) sobrava-me em vontade de fazer uma educação com qualidade e diferenciada.

Comecei em classes nas quais os alunos chegavam a ter 16 anos, ou seja, apenas dois anos mais novos que eu. Eram turmas consideradas difíceis, com alunos com problemas de "comportamento" que afrontavam os professores e causavam muitos transtornos. Foi o que me disseram. Não foi o que vivi.

Talvez pela proximidade da idade, talvez porque cheguei à escola com o firme propósito de não ser uma professora "tradicional" (embora não soubesse muito bem o que isso significasse), o fato é que fui uma professora com poucos problemas com os tais alunos difíceis. 
No mesmo ano, comecei também minha formação na universidade e fui contratada por mais um período de aula, com uma turma de segunda série não totalmente alfabetizada. Ministrava aulas de manhã e à tarde e entrava na universidade às $18 \mathrm{~h} 10 \mathrm{~min}$, onde ficava até às $22 \mathrm{~h} 30 \mathrm{~min}$, de segunda a sexta. Nos sábados de manhã, havia ainda as atividades na escola e, à tarde, as inúmeras reuniões do Partido Comunista em que eu militava.

Ainda em 1984, prestei o primeiro concurso para um cargo efetivo e fui aprovada. A partir de 1985, iniciei então o trabalho numa nova condição: em 22 horas eu era professora efetiva e, nas outras 22 horas, continuava como professora contratada, atuando onde houvesse necessidade, especialmente em substituições de curta duração em diferentes escolas da região e em diferentes turmas, especialmente as de alfabetização

Em 1988, após já ter concluído o curso de Pedagogia na UFMS, fui aprovada em um novo concurso para completar minhas 44 horas semanais. Comecei a ministrar aulas no curso noturno, trabalhando com alunos de EJA, pois meu concurso ainda era para professora dos anos iniciais. Assumi esse segundo concurso na escola Elvira Mathias, no mesmo bairro onde já trabalhava o outro período, mas que, pela localização da escola, atendia crianças e jovens ainda mais pauperizados. Construído no bojo de um projeto de extensão da rede física, o prédio escolar também era diferente. Nesse projeto, as escolas eram feitas em blocos pré-moldados, com paredes muito finas, que permitiam que se ouvisse a aula dada na sala ao lado. Nessa escola, especialmente, não havia muros, o que não era uma opção pedagógica, e sim retrato da precarização. Muitas vezes, ministrei aulas com os meninos das diferentes gangues existentes no bairro assistindo às aulas nas janelas, sentados em suas bicicletas. Muitas vezes, eu os convidei para entrar e sentar conosco, para horror da direção da escola. Eles nunca aceitaram. Não sentiam que ali fosse seu lugar; entendi muito mais tarde.

A experiência com a EJA foi igualmente marcante. As histórias que ouvia dos alunos (não trabalhei com alfabetização nessa modalidade; eram pessoas já alfabetizadas) que atendia eram cortantes. Uma delas me contou um dia que uma professora a havia obrigado a comer uma prova e engolir o papel. Outro, que devia ter no máximo 15 anos, trabalhava como ajudante de mecânico durante o dia. Chegava sempre com as mãos muito sujas e dormia durante as 
aulas. Eu não tinha coragem de acordá-lo. Muitas vezes, falei mais baixo para deixá-lo dormir, porque não sabia muito bem o que fazer com ele.

Em 1990, resolvi fazer um concurso para atuar como professora no Magistério, na área de psicologia. Fui aprovada novamente e, então, abandonei a EJA.

Até 1992, ano em que fiz o concurso para a UFMS, atuei como professora alfabetizadora e professora de psicologia no curso de magistério.

Como alfabetizadora, vivi as melhores experiências como educadora. Sempre fui fascinada pela língua escrita e levar as crianças a esse "mundo no papel" era, para mim, totalmente recompensador.

Uma das primeiras experiências que vivi como alfabetizadora aconteceu, na verdade, um pouco antes de assumir uma classe de alfabetização. Comecei a ministrar aulas numa turma de segunda série (atual terceiro ano) e tinha um aluno não alfabetizado. Ele era atento, excelente copista, dedicado, mas não conseguia ler absolutamente nada. Eu não tinha ideia do que fazer com ele e não tinha em quem buscar ajuda. Um dia, esse menino brincava no recreio, caiu e teve uma fratura muito feia no cotovelo. Tive que acompanhá-lo até o Pronto Socorro, pois a mãe estava no trabalho. Ele precisava de uma cirurgia, entretanto havia lanchado e, por isso, não poderia tomar a anestesia necessária. Sentia muita dor e chorava. Em alguns momentos, eu chorava junto, completamente incapaz de amenizar o que ele sentia. Num dado momento, no auge da dor e talvez por causa dos medicamentos que lhe davam, começou a delirar e repetia frases da cartilha em que, provavelmente, havia estudado no ano anterior. Aquilo me tocou profundamente.

A vontade daquele menino de aprender a ler me fez tomar uma decisão: iria alfabetizá-lo. Após muitos dias de hospital, ele voltou para a escola e cumpri minha promessa. Ensinava-o no contraturno, quando podia, ou ao final da tarde, antes de ir para a universidade. Consegui alfabetizá-lo e, até onde pude acompanhar (a mãe sempre se mostrou muito grata e fazia questão de me dar notícias do desempenho do filho), não teve problemas nas séries posteriores. Foi uma das primeiras grandes lições que tive como alfabetizadora: se você encontrar, em qualquer série, uma criança que não tenha sido alfabetizada, é preciso ter o compromisso ético e político de, pelo menos, tentar ensiná-la a ler. 
Acho que foi com esse menino (João Aroldo, seu nome) que percebi o quanto essa tarefa de ensinar alguém a ler era encantadora.

$\mathrm{Na}$ escola onde trabalhei durante a maior parte do tempo em que estive na rede, consegui, por algum tempo, viver uma experiência coletiva enriquecedora. Com duas jovens professoras que assumiram os concursos nas vagas das professoras contratadas que não haviam sido aprovadas em 1985, estabeleci um profundo laço de amizade (que permanece forte até hoje). Também com elas, incluí-me em um grupo de estudo para estudar a teoria piagetiana e repensar a prática pedagógica. $\mathrm{O}$ grupo de estudo foi proposto pela Léa, minha professora de sociologia na UFMS, que estudava conosco aos sábados em sua casa. Começamos então a desenvolver uma prática pedagógica tentando seguir os princípios construtivistas piagetianos bastante em voga à época. Fazíamos um trabalho coletivo, cada uma de nós em uma série, e garantíamos, com a direção da escola, que as turmas fossem compostas seguindo esse critério: começariam na pré-escola e terminariam na segunda série, passando pelas três professoras. Além de estudarmos juntas e pensarmos propostas para os três anos em que atuávamos juntas, conseguimos também, por meio de promoções e vendendo coisas em barracas nas festas juninas da escola, montar um bom acervo de literatura infantil, que usávamos com as crianças todos os dias. Minhas companheiras de trabalho foram as professoras Marli Zibete e Sonia Maria Ribeiro de Souza, ambas, hoje, professoras universitárias também.

A experiência durou em torno de três anos e foi muito importante para os aprendizados que tive. Em 1988, uma das professoras foi embora e eu fui convidada para compor a equipe de alfabetização da Agência Especial de Educação de Campo Grande. Essa experiência foi bastante curta: ao final de um bimestre, com a mudança do Secretário de Educação, a equipe foi desfeita.

Durante todo o tempo em que trabalhei como alfabetizadora, nunca adotei cartilha. Fazia a experiência com as crianças (uma época tentando seguir o método global e, posteriormente, as ideias de Emília Ferreiro) e compunha com elas os próprios textos. Além de ler com elas muitas histórias, escrevíamos todas nossas experiências com as aulas diferenciadas que fazíamos.

Fazíamos coisas que hoje eu não teria coragem de fazer, como, por exemplo, ministrando aulas em uma periferia muito distante da área central de 
Campo Grande, colocar nossos alunos em ônibus coletivos e ir para as praças do centro da cidade, aos (poucos) museus existentes, ou levá-las para assistir a peças de teatro no Teatro Glauce Rocha, na universidade. Era uma aventura para os pequenos e para nós professoras, mas, certamente, algo arriscado, que hoje eu não só não faria, como não recomendaria.

Em 1991, tive um grave problema nas cordas vocais (nódulo), que me fez perder a voz e precisar afastar-me por 6 meses da sala de aula. Além da classe de alfabetização, para completar minha carga horária de Psicologia no Magistério, eu ministrava aulas em mais 17 turmas, espalhadas por três escolas diferentes, cada uma numa região de Campo Grande. Isso agravou seriamente um problema que já vinha persistindo há algum tempo: perdas temporárias da voz. Chegou um momento em que fiquei completamente afônica e tive que me afastar das atividades didáticas. Para quem trabalha com classes de alfabetização, afastar-se durante um período letivo é um verdadeiro pesadelo. Sem saber quando poderia assumir novamente os encargos didáticos, ficava sem saber como encontraria minha turma ao final da licença.

Ao final do ano de 1991, recebi um convite para atuar como técnica da UIAP (Unidade Interdisciplinar de Apoio Psicopedagógico). Era um órgão ligado à Secretaria de Educação e que realizava um trabalho de atendimento às escolas para fazer diagnóstico de crianças com possíveis problemas de aprendizagem e dar os encaminhamentos necessários. $O$ trabalho de diagnóstico era realizado por uma dupla composta por uma pedagoga e uma psicóloga.

A partir de 1992, deixei então as escolas e fui trabalhar como técnica da UIAP. Meus problemas com a voz continuavam e o tipo de trabalho que realizaria me traria uma possibilidade de poupar esforço vocal.

A ida para a UIAP permitiu-me também voltar a estudar, coisa que ficava cada vez mais difícil atuando em dois períodos na escola.

\subsection{O trabalho na Universidade Federal de Mato Grosso do Sul}

Logo no início de 1992, foi anunciado um grande concurso de professores para a Universidade Federal de Mato Grosso do Sul, especialmente para os campi do interior do estado. Vários dos meus amigos oriundos do movimento estudantil e sindical, agora professores, resolveram inscrever-se. O edital exigia 
apenas graduação e isso ia contra uma das pautas do movimento estudantil (ME) do qual fiz parte, que preconizava que, para ser professor da UFMS, fosse exigido no mínimo mestrado. Após muitas dúvidas e incertezas e com muitas discussões com companheiros que, como eu, vinham do ME e do MS (movimento sindical), decidi inscrever-me para uma vaga de Didática e Metodologia do Ensino para o Campus de Corumbá. Era uma vaga e 18 inscritos. Consegui ler toda a bibliografia sugerida no edital e preparar todos os temas apresentados. Preparei-me da melhor forma possível para o exame.

Fiz o concurso e obtive as melhores notas, tanto na prova escrita como na didática. Tive cinco notas nove e uma nota dez. Fiquei em primeiro lugar em notas, mas o concurso era de provas e títulos, e eu não tinha títulos. Não havia feito especialização e as poucas coisas que tinha, que poderiam contribuir para a minha classificação, eu não havia comprovado. Assim, por uma diferença de três décimos entre mim e o primeiro colocado (houve empate no segundo e terceiro lugar), minha classificação caiu para o quarto lugar, o que me levou a imaginar que jamais seria chamada a assumir uma vaga. Mesmo assim, fiquei muito feliz pelas notas que obtive.

Alguns meses depois, entretanto, recebi uma consulta se tinha interesse em assumir a vaga, que originalmente era para Corumbá, no Campus de Três Lagoas. Os três primeiros colocados já haviam assumido suas respectivas vagas em Corumbá e havia uma possibilidade de ir para Três Lagoas. Em novembro de 1992, pedi demissão dos cargos que ocupava como professora da Rede Estadual de Ensino de Mato Grosso do Sul e assumi, no dia 10 de novembro, o cargo de professora da Universidade Federal de Mato Grosso do Sul. Nesse mesmo dia, cheguei a Três Lagoas com duas malas e um medo enorme de que as coisas não dessem certo, mas, ao mesmo tempo, com muita esperança. Sentia-me muito orgulhosa de ser professora da universidade.

Minhas atividades como docente na UFMS, nos primeiros anos, resumiram-se em "dar aula", muitas aulas. Ministrei aulas de praticamente todo o currículo do curso de Pedagogia. Era a professora mais nova do curso, sem títulos e, portanto, assumia os encargos que fossem necessários. Também, pela minha formação incipiente, não sabia como fazer pesquisa ou extensão. Sabia dar aula e esforçava-me ao máximo para fazer isso bem feito; estudava o tempo 
todo, mas só fui aprender sobre pesquisa e extensão quando já estava no mestrado.

Trabalhei com uma disciplina que havia no currículo apenas como optativa e que era, de longe, a que mais me interessava. Posteriormente, tornou-se disciplina obrigatória, passando por diferentes nomes, mas que se transformou numa das principais disciplinas com as quais trabalho: Metodologia do Ensino da Alfabetização.

As outras disciplinas que assumi e que têm sido constantes em meu currículo foram Sociologia e Sociologia da Educação. A professora que ministrava a disciplina aposentou-se e eu pude, então, sob forte influência da excelente professora de Sociologia que havia tido, trabalhar com essa disciplina.

Pelo fato de ser nova nos quadros da UFMS, tive, entretanto, que assumir disciplinas sobre as quais não tinha o menor domínio, como, por exemplo, Educação Brasileira. Foi excelente para a minha formação, pois precisei estudar e aprender os conteúdos propostos, mas foi também desesperador. Dizia aos alunos, com toda honestidade possível, que eu havia estudado um determinado período para aquela aula (Brasil Colônia, por exemplo) e que, se eles quisessem saber algo sobre o próximo período (Brasil Império, neste caso), iriam precisar esperar o nosso próximo encontro para que eu pesquisasse, estudasse e trouxesse a resposta. Foram diferentes disciplinas ministradas nesses 26 anos, mas, nos últimos anos, especialmente após concluir o doutorado em 2003, pude fixar-me melhor nas que tratam da alfabetização e nas da área de Sociologia.

Após a conclusão do mestrado, em 1998, tive mais claro o meu papel como professora universitária. Entendi melhor o que poderia fazer em relação à pesquisa e extensão universitárias e, a partir daí, consegui elaborar projetos que atendessem, finalmente, ao tripé sobre o qual está estruturada a universidade. No mesmo ano em que concluí o mestrado, fui aprovada na seleção de doutorado e, no ano seguinte, afastei-me para cursar, dessa vez com dedicação integral aos estudos, o curso de doutorado na USP.

$\mathrm{Na}$ volta do doutorado, em 2003, envolvi-me com diferentes projetos de pesquisa e extensão e, a partir de 2005, coordenei, juntamente com outra professora do curso de Pedagogia e a participação de vários professores do curso, o que viria a ser transformado, logo em seguida, em um programa de extensão financiado pelo Proext. 


\section{ATIVIDADES DESENVOLVIDAS ENTRE 2011 E 2018}

\subsection{Ensine, professora, ensine! (Carta número 4)}

Querida jovem amiga:

O verbo "ensinar", por algum tempo, foi um tanto malvisto na educação nacional, você deve ter percebido ao estudar História da Educação Brasileira em seu curso de formação. Pois bem, eu, particularmente, acho que não devemos ter medo de usá-lo. Ensinar e aprender fazem parte do nosso processo de humanização. Tudo depende da postura que quem ensina ou aprende assume. Assim, devo the dizer que não tenha medo de ensinar, mas, ao mesmo tempo, advertir que também não esqueça o que nos disse o velho Guimarães e que é repetido ad nauseam em muitos lugares, mas, mesmo assim, não deixa de ser verdadeiro e belo: "Mestre não é quem sempre ensina, mas quem, de repente, aprende".

Ensinar é, para mim, assumir de forma séria e responsável a tarefa de socializar os conhecimentos historicamente acumulados pela humanidade (isso também tem sido repetido ad nauseam, eu sei). Passamos por períodos em que, pelo menos no ideário pedagógico, os professores apresentavam certo receio de dizer que ensinavam. Acho que, na alfabetização, especialmente, isso se consolidou de forma muito forte nos anos 1980. Tenho pra mim que é resquício lá do movimento escolanovista dos anos de 1930, que insistia em dizer que o aluno era o centro do processo (acertadamente, mas, logicamente, junto com o professor e os conteúdos ensinados) e que ensinar não era necessário. O mais importante era aprender a aprender, se lembra disso? Foram muito comuns, durante os anos de 1980, época em que iniciei a docência, os discursos contra os processos diretivos de ensino e o desejo de que deixassem as surpresas da sala de aula acontecerem!

Pois bem, se, para os filhos das camadas médias e das elites, é possível se pensar em experiências menos diretivas com o processo de ensino tendo em vista os conhecimentos e o capital cultural que já trazem (e que sempre coincidem com o que é cobrado e esperado na escola), o mesmo não se pode dizer das crianças com origem nas camadas populares. Para elas, a única forma de chegar ao conhecimento historicamente acumulado (e aquele que será cobrado por meio dos conteúdos e códigos escolares) é por via escolar. Isso não quer dizer que esse processo precise ser sisudo e desinteressante. Não. Mas também não é um eterno domingo de férias, lembra? Apoderar-se desses conhecimentos exige disciplina, exige tempo, exige uma boa vontade em relação a esses saberes. E exige, principalmente, um grande compromisso ético, técnico e político de nós professores. Portanto, não tenha medo de ensinar. De organizar suas aulas. De dar direção. Se fizer isso estando também aberta para as aprendizagens que chegarem, será perfeito.

Então, reafirmo a você nesta carta a necessidade de o professor ensinar. Ensinar com profundo respeito aos alunos, aos saberes que eles já portam. Ensinar com cuidado e também, se possível, com afeto. E estar também, ao mesmo tempo, com disposição para aprender. E, assim, nesse processo de ensinos e aprendizagens, constituir-se humano.

Abaixo, um trecho do belíssimo relato de Carlos Drummond de Andrade sobre meninos, professora e escrita:

"Foi aí que nasci: nasci na sala do terceiro ano, sendo professora Dona Emerenciana Barbosa, que Deus a tenha. Até então era analfabeto e despretensioso. Lembro-me: nesse dia de julho, o sol que descia da serra era bravo e parado. A aula era de geografia, e a professora 
traçava no quadro negro nomes de países distantes. As cidades vinham surgindo na ponte dos nomes, e Paris era uma torre ao lado de uma ponte e de um rio, a Inglaterra não se enxergava bem no nevoeiro, um esquimó, um condor surgiam misteriosamente, trazendo países inteiros. Então, nasci. De repente nasci, isto é, senti necessidade de escrever."

Um grande abraço, com o desejo de que, como dona Emerenciana Barbosa, você desperte em muitos meninos e meninas a vontade de escrever!

Te abraço afetuosamente,

3.2 Atividades de ensino na educação superior: graduação e pós-graduação

As atividades de ensino às quais me vinculei desde 1992 aconteceram todas no espaço da UFMS, mas em três campi diferentes: as de graduação, no campus de Três Lagoas, CPTL, e as de pós-graduação, primeiramente em Campo Grande e, posteriormente, em Corumbá. Em face do período em que se circunscreve este memorial, descrevo as atividades desenvolvidas em Três Lagoas, na graduação, e, em Corumbá e Três Lagoas, na pós-graduação tendo em vista que minha participação no mestrado em educação de Campo Grande foi em um período anterior (de 2007 a 2009) ao delimitado, pela UFMS, para este documento.

As aulas na graduação sempre foram, para os professores dos campi do interior na UFMS, em números excessivos, especialmente para quem, como eu, também atua na pós-graduação. Entretanto, dada a falta de professores e das especificações das áreas de conhecimento, cada um acaba por responsabilizarse por determinadas disciplinas e precisa "dar conta" delas. Em alguns anos, especialmente em momentos de mudança do currículo (para atender as demandas das Pró-Reitorias, do MEC ou mesmo as necessidades do curso), essas disciplinas são duplicadas, gerando problemas sérios em relação à carga horária. Em 2009, por exemplo, cheguei a assumir 28 horas aulas semanais, além de todos os outros encargos com pesquisa e extensão.

As disciplinas ministradas dão a dimensão da extensão do trabalho que precisamos desenvolver quando atuamos em universidades pequenas, especialmente nos centros do interior: aulas na graduação e na pós-graduação, atendendo a diferentes áreas do conhecimento. Nem mesmo a grande divisão já clássica feita nos cursos de Pedagogia entre as disciplinas ligadas aos Fundamentos da Educação e aquelas ligadas às áreas das metodologias 
conseguimos manter. Sempre atuei em disciplinas da área de fundamentos (Sociologia repetidamente, mas também História da Educação e Educação Brasileira) e nas de metodologias, especialmente de alfabetização.

No segundo semestre de 2012, consegui um afastamento para fazer o Pós-Doutorado, que descrevo em outro item deste Memorial, entretanto, logo no início do primeiro semestre, aconteceu uma greve de docentes no setor das Federais da Andes SE. O movimento nacional teve início em 17 de maio de 2012, mas nosso sindicato em Três Lagoas só conseguiu a adesão da categoria a partir do mês de junho. A greve estendeu-se até setembro e, posteriormente à volta, houve a necessidade de reposição dos dias parados. Assim, o semestre estendeu-se até outubro de 2012 e, somente após a conclusão do semestre, pude, efetivamente, desenvolver o estágio pós-doutoral.

As disciplinas da pós-graduação foram oferecidas em dois cursos: no Mestrado em Educação, em Corumbá, cidade que fica a $800 \mathrm{~km}$ de Três Lagoas, onde resido, e no Doutorado em Letras, ao qual me vinculei a partir de 2013, este oferecido em Três Lagoas mesmo.

Meu vínculo com a pós-graduação começou em 2007, no Programa de Pós-Graduação em Educação do Centro de Ciências Humanas e Sociais, em Campo Grande. Nele permaneci até 2009.

Em 2008, recebi um convite para participar da equipe que comporia o quadro de uma nova proposta de mestrado em Educação na cidade de Corumbá. Era uma proposta diferenciada, com área de concentração em Educação Social. O grupo de professores que estava sendo formado eram pessoas com as quais eu tinha muitas afinidades, tanto políticas como pedagógicas. A proposta foi aprovada e, em 2009, iniciamos as atividades. Como grande parte dos professores do quadro permanente eram de outros campi, as disciplinas, mesmo as obrigatórias, eram oferecidas por dois professores conjuntamente e a cada 15 dias, em período integral, e não semanalmente. Assumi, juntamente com a professora Ana Maria Santana da Silva, amiga de militância do Movimento Estudantil (ME), do Partido dos Trabalhadores e do Movimento Sindical (MS), tanto na rede pública como na universidade, a disciplina que havíamos proposto para o curso: Fundamentos Históricos e Filosóficos da Educação. Fizemos um recorte e optamos por trabalhar apenas com a educação brasileira. Além dos encargos com disciplina obrigatória, também ministrei, em alguns semestres, as 
optativas sobre alfabetização e letramento idealizadas por mim, algumas vezes sozinha e, na maior parte, dividindo também com uma ou duas professoras os encargos didáticos (professora Lucimar Rosa Dias e professora Regina Aparecida Marques de Sousa). Nessas disciplinas, pude trabalhar um pouco do que vinha também pesquisando: a questão do letramento em meios populares. Assumi também uma média de dois a três orientandos por ano.

Embora o trabalho realizado em Corumbá fosse extremamente prazeroso, especialmente pela grande sintonia que havia entre o grupo (coisa rara em programas de pós-graduação, como todos sabemos), havia um problema sério: a grande distância entre Corumbá e Três Lagoas $(800 \mathrm{~km})$. A viagem era feita de ônibus, o que me tomava de 12 a 15 horas para a ida e o mesmo tempo para a volta. Além dos meus afazeres no curso de Pedagogia (somente por um semestre tive a carga horária na graduação diminuída para 4 horas), estava ainda com um filho pequeno ( 6 anos) e coordenava atividades de extensão e pesquisa. A rotina era quase sempre a mesma: uma vez por mês, saía de Três Lagoas em um ônibus, às 14 horas, para chegar a tempo de embarcar no de $23 \mathrm{~h} 30$ para Corumbá. Viajava a noite inteira, chegava ao destino às 6 da manhã, ministrava aulas das $8 \mathrm{~h}$ ao meio dia e das $14 \mathrm{~h}$ às $18 \mathrm{~h}$. À noite, fazia reunião com minhas orientandas ou participava das reuniões de colegiado. E, às $23 \mathrm{~h} 30 \mathrm{~min}$, entrava no ônibus de volta a Campo Grande e, de lá, às 7 da manhã, embarcava para Três Lagoas, aonde só chegava ao meio dia. Em algumas idas, ficava um dia a mais para as bancas e outras atividades.

Consegui manter minha participação oferecendo disciplina obrigatória por cinco anos, até 2013. Nesse ano, quando voltei do pós-doutorado em agosto, enfrentei um novo problema, que me levou a redefinir minhas prioridades. Haviame separado em 2011 e, no início de 2013, meu ex-marido resolveu ir embora de Três Lagoas. Fiquei então sozinha com nosso filho e sem ter ninguém da minha família que pudesse ajudar-me na tarefa de tomar conta dele enquanto viajava. Todas as vezes em que precisava viajar, era preciso realizar uma verdadeira operação de guerra: ou levar meu filho comigo até Campo Grande e deixá-lo sob os cuidados de minha irmã (e isso trazia como consequência a ausência dele na escola), ou precisava deixá-lo na casa de um casal de amigos em Três Lagoas (coisa a que até hoje recorro em momentos de muita necessidade). Isso significava também encontrar alguém para levá-lo à escola, 
ao inglês e a todas as outras atividades extras que ele fazia. Não me faltaram amigos para me ajudar nessa tarefa, mas era extremamente desgastante, tanto para mim quanto para meu filho.

Diante disso, tomei uma decisão que influenciou não só minhas atividades no mestrado como também todas as atividades que envolvessem viagens, como bancas, eventos, palestras e outras. Decidi, a partir de 2014, parar de oferecer a disciplina obrigatória bem como diminuir drasticamente minha participação em atividades nas quais eu precisasse ausentar-me de Três Lagoas. Assim, a partir de 2014, minhas viagens a Corumbá foram apenas para as orientações e para ministrar algumas disciplinas optativas, sempre em parceria com mais uma ou duas colegas.

Ainda no pós-doc, aceitei o convite dos professores do curso de Letras de Três Lagoas para compor o quadro de professores vinculados ao doutorado que estava sendo criado naquele ano e que iniciaria as atividades em 2014. Organizei uma disciplina sobre Estratégias de Leitura e a ofereci por dois anos consecutivos, além de assumir três (apenas dois registrados) orientandos no curto período em que permaneci no programa. Em 2017, ao precisar renovar minha participação no curso, resolvi que, tendo em vista que, em 2018, eu estaria apta a aposentar-me e sabendo que tinha a séria intenção de efetivar isso, o melhor seria desvincular-me de algumas atividades, dentre elas a do doutorado. Continuei apenas orientando o doutorando que estava comigo desde 2014, cujo trabalho já estava bastante adiantado. Mesmo assim, por um equívoco de orientação do Programa, ao me desligar, não pude assinar o trabalho como orientadora, e sim como coorientadora.

\subsubsection{Orientações realizadas entre 2011 e 2018}

Os trabalhos de orientação entre os anos de 2011 e 2018 concentraramse na graduação e na pós-graduação stricto sensu.

Durante o ano de 2012, em decorrência do afastamento para o pósdoutorado, tive que passar formalmente os orientandos que estavam sob minha responsabilidade para outro orientador. Do ponto de vista formal, não é possível essa vinculação. Do mesmo modo, em 2015, tive, sob minha responsabilidade, 
duas orientandas de outra professora que também se afastou para o pósdoutorado.

Os trabalhos orientados, de forma geral, estiveram sempre ligados à minha área de atuação, tratando sempre de questões sobre alfabetização, leitura ou até mesmo acerca da relação família-escola. Nem todas, mas grande parte delas esteve ligada aos projetos de pesquisas que coordenava. Há uma única exceção nas orientações de mestrado: a de uma aluna que, sendo formada em Educação Física e tendo sido aprovada com um determinado projeto, desejou mudar seu objeto de pesquisa no decorrer do trabalho, investigando uma questão específica de sua área de formação. Por ser uma excelente aluna, com bastante independência e autonomia intelectual, foi possível concluir o trabalho a contento.

\subsection{Atividades de extensão e pesquisa}

\subsubsection{Saia e olhe, professora, saia e olhe! (Carta número 5)}

\section{Minha querida amiga:}

O trabalho na universidade se estrutura sob o tripé do Ensino, Pesquisa e Extensão, mas, confesso a você, demorei um pouco para entender como isso se concretizava na prática. Me tornei professora universitária muito jovem, aos 26 anos, sem ter terminado meu processo formativo. Era apenas graduada e, em minha época de graduação, poucos professores se dedicavam à pesquisa. Como, além de tudo, ainda fui estudante trabal hadora, não pude viver a universidade como deveria. Isso me fez chegar à posição de professora sem entender muito bem o tal tripé.

Pois bem, hoje posso dizer - e realmente digo aos meus jovens alunos - que a pesquisa nos permite produzir conhecimentos; a extensão e o ensino, a compartilhá-los. O que é preciso fazer para produzir extensão? Isso só é possível na universidade? E a pesquisa? Então, para mim, é possível fazer as duas coisas na escola pública e acho que eu mesma o fiz sem saber e de uma forma um tanto intuitiva. Hoje já existem linhas de pesquisa preocupadas em estudar e orientar o professor pesquisador da própria prática. O que irá caracterizar a pesquisa de forma clara é você ter um problema que queira entender melhor. E isso pode ser, sem dúvida nenhuma, uma situação concreta de sua classe. Saber como outras pessoas pensaram esse problema e como seu trabalho irá preencher alguma lacuna sobre isso é fundamental. A pesquisa deve sempre lançar um olhar novo sobre uma (talvez velha) questão. Então, é possível, sim, fazer pesquisa. Não podemos, entretanto, banalizar a pesquisa e considerar qualquer coisa como sendo. Há padrões e rigores para que um trabalho seja considerado verdadeiramente um trabalho de pesquisa e é importante saber sobre eles. 
Outra coisa importante que devemos fazer como professores é sair dos muros da escola. Fazer projetos que envolvam as famílias, as crianças, os vizinhos e até mesmo aqueles que não têm filhos em idade escolar. A escola deveria ser sempre um polo onde pudéssemos reproduzir a cultura mais elaborada em todas as suas manifestações. E isso parece que ficará a cada dia mais difícil nesses novos tempos. O primeiro passo para se fazer pesquisa é o olhar atento. Olhar e ver algo interessante onde ninguém mais viu. Uma fala de um aluno, uma pergunta de um pai, a relação com um livro, um projeto proposto pela secretaria. O primeiro passo para fazer extensão é sair dos muros da escola, repito. Ou melhor: abrir os portões, deixar que as pessoas venham até nós e ir também até elas. Esses encontros são poderosos e podem mover engrenagens importantes. Portanto, cara amiga, saia e ol he, sempre que possivel!

Pensei muito em qual poema combinaria com esta carta. Achei uma música do Gonzaguinha da qual gosto muito e que fala dessa necessidade de estar com outros, com os iguais, com os diferentes. Se chama Caminhos do coração. Segue aí então!

Caminhos do corạ̧ão

Há muito tempo que eu saí de casa

Há muito tempo que eu caí na estrada

Há muito tempo que eu estou na vida

Foi assim que eu quis, e assim eu sou feliz

Principalmente por poder voltar

A todos os lugares onde já cheguei

Pois lá deixei um prato de comida

Um abraço amigo, um canto pra dormir e sonhar

E aprendi que se depende sempre

De tanta, muita, diferente gente

Toda pessoa sempre é as marcas

Das lições diárias de outras tantas pessoas

E é tão bonito quando a gente entende

Que a gente é tanta gente onde quer que a gente vá

E é tão bonito quando a gente sente

Que nunca está sozinho por mais que pense estar

É tão bonito quando a gente pisa firme

Nessas linhas que estão nas palmas de nossas mãos

É tão bonito quando a gente vai à vida

Nos caminhos onde bate, bem mais forte o coração

Beijos ao vento pra você, querida amiga! Ana

A partir de 2003, com meu retorno após o período de afastamento para fazer doutorado, procurei sempre vincular minhas atividades de pesquisa às de 
extensão. Em 2011, ainda estava em fase de conclusão o projeto de extensão denominado "Mães, crianças e livros: incentivando práticas de letramento em meios populares", que era vinculado ao projeto de pesquisa encerrado em 2010: "Mães, crianças e livros: investigando práticas de letramento em meios populares".

A parte extensionista do trabalho centrava-se em, juntamente com um grupo de alunos bolsistas de Iniciação Científica e Extensão, ir até a escola uma vez por semana e contar histórias de literatura infantil previamente selecionadas para as mães e as crianças. Acreditávamos que isso levaria a novas práticas letradas e, talvez, à incorporação da leitura do livro de literatura infantil nos hábitos familiares. O trabalho extensionista foi de 2007 até 2011. As avaliações, tanto pelos sujeitos envolvidos como pelos pesquisadores em formação, foram positivas: realmente terá havido avanço nas práticas letradas desenvolvidas pelas famílias. Alguns dos resultados foram publicados em artigos. Esse trabalho, coordenado por mim e pela professora Neusa Maria Marques de Sousa, fez parte de um Programa de Extensão do PROEXT, financiado pelo MEC, juntamente com as mais diversas ações (em um ano, chegamos a ter 15 projetos de extensão compondo o Programa).

A parte da pesquisa do "Mães, crianças e livros" foi concluída em 2010. Foi um projeto que contou com financiamento do CNPq e que rendeu diversas publicações durante seu período de vigência.

Ainda em 2010, elaborei o Projeto de pesquisa "Letramento em meios populares: retratos de leitores", que viria a ser desenvolvido em três momentos distintos (descritos adiante). Procurei dar continuidade à mesma temática tratada no "Mães, crianças e livros", mas com um novo problema investigativo.

O primeiro momento do trabalho foi realizado com sujeitos universitários que fizessem parte da primeira geração da família a viver escolarização de longa duração. Foram aplicados questionários a alunos dos cursos de Pedagogia, História e Geografia que estavam cursando terceiro e quarto ano no campus de Três Lagoas (em torno de 60 alunos). Os questionários foram aplicados à totalidade dos alunos frequentes, buscando informações sobre a origem familiar, experiências de escolarização de longa duração vivida pelas famílias e relação com a leitura. A partir dos questionários, selecionamos, para entrevistas aprofundadas, um grupo de sujeitos que cumpriam três requisitos: pertencer à 
primeira geração da família a viver a experiência de longevidade escolar; reconhecer-se e afirmar-se como leitor e ter suas origens ligadas às camadas populares.

A segunda parte da pesquisa, iniciada em 2011 e somente concluída em 2014, foi realizada por uma aluna de mestrado. A princípio, a ideia era trabalhar com um grupo de sujeitos altamente escolarizados, constituído por professores doutores da Universidade Federal de Mato Grosso do Sul. Entretanto, após inúmeros acertos entre a pesquisa proposta e o que a mestranda realmente gostaria de fazer, acabamos ficando com um trabalho que se concretizou trazendo o retrato de leitores altamente escolarizados, buscando mostrar como foram suas relações com a leitura, desde o acesso aos materiais escritos, quem proporcionou a relação com estes materiais e quais tipos de leitura foi e é mais frequentes em seu cotidiano.

Finalmente, a última parte do trabalho foi realizada por mim durante o estágio pós-doutoral na Universidade Federal Fluminense, de agosto de 2012 a julho de 2013, sob a supervisão da professora Cecília Goulart. Durante o estágio pós-doutoral trabalhou-se especificamente com o grupo de sujeitos com pouca ou nenhuma escolarização e que se reconheciam como leitores. Essa parte da pesquisa foi concluída em 2013; a pesquisa completa, em 2015.

A conclusão do Pós-doutorado encerrou a terceira parte da pesquisa proposta com a produção de muitos dados sobre os retratos de leitores encontrados em meios populares.

\subsection{Coordenação de grupo de pesquisa}

Criamos, em 2007, eu e a professora Neusa Maria Marques de Souza, o Grupo de Estudos e investigação sobre alfabetização, letramento e letramento matemático. Em 2008, obtivemos financiamento da Fundect/MS para a montagem de um laboratório com o objetivo de constituição de um laboratório de estudos e investigação sobre alfabetização, letramento e letramento matemático - ALLEM - que teve como mote os estudos sobre práticas de letramento em ambiente escolar e não-escolar.

O grupo de estudo com o mesmo nome, vinculado ao laboratório, ficou sendo coordenado apenas por mim após a aposentadoria da professora Neusa. 
A partir de 2016, a professora Regina Aparecida Marques de Souza passou a integrar o grupo e a contribuir com os estudos sobre a teoria vigotskyana. $O$ grupo já acolheu professores da rede por alguns anos, mas, apesar de continuar aberto para os professores, tem como prioridade os alunos vinculados à UFMS. Hoje, fazemos reuniões semanais apenas com um grupo de alunos e ex-alunos vinculados à graduação e à pós-graduação. $O$ grupo foi criado com o objetivo de, pautado nos princípios de horizontalidade nos diálogos, responsabilidades compartilhas das discussões teóricos/práticas, encaminhar estudos e reflexões acerca das questões relativas à alfabetização, letramento e letramento matemático. A metodologia de trabalho adotada pelo grupo é de discussões de textos teóricos em uma das reuniões semanais e, na outra, de discussão de trabalhos práticos desenvolvidos nas escolas pelos componentes.

3.5 Participação em bancas de defesa de monografias, teses e dissertações

A atuação em bancas de avaliação de trabalhos de conclusão é das atividades mais recorrentes no trabalho do professor universitário e uma das mais trabalhosas. José Paulo Netto afirma, em uma palestra, que muitas vezes gostaria de estar estudando algum autor clássico, mas gasta o tempo em leituras de trabalhos que precisa orientar ou avaliar. Ler e interferir no trabalho de alguém é, acima de tudo, um exercício de delicadeza, tanto como orientador quanto como membro de banca. Contribuir para a formação de novos pesquisadores é uma tarefa bonita, difícil e que precisa ser feita com zelo e afeto.

\subsection{Produção intelectual}

\subsubsection{Escreva, professora, escreva! (Carta número 6)}

\section{Cara amiga:}

Sei o quanto é difícil escrever. Como iá disse Drummond, "Lutar com palavras é a luta mais vã". Mas, sim, é preciso. Confesso a você que, nos últimos tempos, a escrita acadêmica cheia de regras e prisões - me tem sido pouco atrativa. Tenho a impressão de que se escreve muito e se lê pouco, o que é sempre um perigo, porém penso que precisamos, sim, escrever. Escrever, de alguma forma, nos ajuda a encontrar nosso lugar no mundo. Relate suas experiências, conte sobre o que ensina e como ensina, fale sobre como seus alunos aprenderam determinadas coisas. Às vezes, temos dúvida se isso ajudará outros professores, porque parece 
que fazemos o óbvio. Mas não é. Saber como um professor concreto que dá aula numa localidade parecida com a sua resolveu uma determinada questão pode ajudar muito a outros professores com os mesmos problemas.

E também escrevemos porque a escrita é a extensão da nossa memória. Por ela, conseguimos, como diz o título de um livro bastante interessante, colocar "O mundo no papel". A escrita (não só ela) nos permite pensar sobre o que vivemos. Ao escrever, revisitamos, podemos rever, repensar e traçar novos caminhos.

Tente, sempre que possivel, fundamentar o que escreve. É o seu olhar sobre um determinado problema, mas certamente outras pessoas iá pensaram sobre aquilo. Não se contente, no entanto, em apenas repetir. Arrisque-se sempre a pensar e a entender a realidade concreta. A gente nem imagina sobre quantas coisas há outros professores pensando num dado momento. Ah, e também tente escrever sobre aquilo que te toca e sobre o que você acha que tenha realmente algo importante a dizer. Não siga a moda, o que as agências de financiamento esperam ou o que seu orientador determina. Escreva onde você acha que sua escrita irá reverberar e onde você possa realmente contribuir para aquela temática. Não há nada mais triste do que pessoas que mudam seus discursos, suas pesquisas e, portanto, seus escritos, ao sabor do que é esperado no intuito de conseguir financiamentos, títulos ou qualquer outra coisa.

Precisamos, sim, escrever; mas precisamos, urgentemente, escrever coisas que realmente possam impactar as práticas e as reflexões nas escolas. Escrever para outros professores, para que eles leiam e entendam. Isso não significa, em momento algum, ser raso, sem profundidade, e sim buscar um estilo que possa ser compreendido. Bourdieu disse um dia, em uma entrevista, ao ser indagado por que escrevia de forma tão hermética e difícil, que o objeto que ele se propunha compreender era difícil e, portanto, não podia escrever fácil. Mas, e se pudermos, de algum modo, traduzir a complexidade desse objeto para que mais pessoas possam nos entender melhor? Para quem afinal, escrevemos? Sempre quis escrever para a professora que fui, que dava 40 aulas na rede pública, que tinha uma quantidade infinda de angústias e que buscava nos textos acadêmicos um alento e uma forma de melhor entender o que se passava na sala de aula.

Nosso objeto de reflexão é difícil mesmo, mas nosso papel é torná-lo compreensivel, especialmente para os professores que precisam melhor entendê-lo.

Por falar em escrever, quero que você leia esse moço aqui da nossa terra, chamado Manuel de Barros, e o que ele diz sobre isso:

O Menino Que Carregava Água Na Peneira Tenho um livro sobre águas e meninos. Gostei mais de um menino que carregava água na peneira.

A mãe disse que carregar água na peneira era o mesmo que roubar um vento e sair correndo com ele para mostrar aos irmãos. A mãe disse que era o mesmo que catar espinhos na áqua O mesmo que criar peixes no bolso.

O menino era ligado em despropósitos. 
Quis montar os alicerces de uma casa sobre orvalhos. A mãe reparou que o menino gostava mais do vazio do que do cheio.

Falava que os vazios são maiores e até infinitos.

Com o tempo aquele menino que era cismado e esquisito porque gostava de carregar água na peneira. Com o tempo descobriu que escrever seria o mesmo que carregar água na peneira. No escrever o menino viu que era capaz de ser noviça, monge ou mendigo ao mesmo tempo. O menino aprendeu a usar as palavras.

Viu que podia fazer peraltagens com as palavras.

E começou a fazer peraltagens.

Foi capaz de interromper o voo de um pássaro botando ponto final na frase.

Foi capaz de modificar a tarde botando uma chuva nela.

O menino fazia prodígios.

Até fez uma pedra dar flor!

A mãe reparava o menino com ternura.

A mãe falou:

Meu filho você vai ser poeta.

Você vai carregar água na peneira a vida toda.

Você vai encher os vazios com as suas peraltagens

e algumas pessoas vão te amar por seus

despropósitos.

Com grande abraço e carinho e com o desejo de que a escrita, para você e seus alunos, seja também e sempre esse espaço de peraltagens!

\section{ATIVIDADES ADMINISTRATIVAS E DE REPRESENTAÇÃO}

\subsection{Escolha, professora, escolha! (Carta número 7)}

Querida professora:

Em nossa carreira, precisamos desempenhar diferentes papéis de que nem sempre gostamos ou aos quais não nos consideramos aptas. O que gostaria de te dizer sobre isso é: você tem o direito de escolha. Sim. Não precisamos cumprir tudo o que esperam de nós. Eu mesma nunca fui afeita às burocracias, às "oficialidades", ao formalismo. Sofri muito por isso. Fugi o quanto pude de todos os cargos burocráticos e até mesmo representativos que 
quiseram me impor. Só fiz o extremamente necessário e nos momentos em que julquei que estaria sendo egoísta se não contribuísse. Não me sinto mal por isso, pois sempre trabalhei muito em outras coisas.

Mas sei também que nem sempre é possível dizer "não". Quando não for possível, tente fazer da melhor forma. E o que posso te dizer é: não é nenhum bicho de sete cabeças. ou é. Mas a gente dá conta. Destruindo uma cabeça por dia apenas e não olhando para as outras seis.

Portanto, cara amiga, não sinta vergonha de escolher!

Olha que maravilha este quase conselho do Mário Quintana:

Canção do dia de sempre

Tăo bom viver dia a dia...

A vida assim, jamais cansa...

Viver tão só de momentos

Como estas nuvens no céu...

E só ganhar, toda a vida,

Inexperiência... esperança... E

a rosa louca dos ventos Presa à

copa do chapéu.

Nunca dês um nome a um rio:

Sempre é outro rio a passar.

Nada jamais continua, Tudo

vai recomeçar!

E sem nenhuma lembrança

Das outras vezes perdidas,

Atiro a rosa do sonho

Nas tuas mãos distraídas...

Vamos atirar a rosa do sonho minha amiga!

Com carinho,

Ana.

Nunca gostei das burocracias e, por isso, um dos pontos onde atuei pouco na vida acadêmica foi em atividades administrativas. $O$ único cargo que ocupei por três vezes no curso de Pedagogia do CPTL foi o de coordenadora de curso, mas no período anterior ao que é preciso circunstanciar neste memorial. Não acho que desempenhe bem as funções administrativas e, embora tenha sido muitas vezes convidada a concorrer a esses cargos (chefe de departamento e diretor de centro, especialmente), nunca me senti atraída por eles. Mesmo a 
coordenação de curso, só me aventurei por um acordo interno no curso de Pedagogia: todos os professores deveriam passar pela experiência e, assim, dividir o ônus pesado de realizar essa tarefa em uma época em que nem redução da carga horária era concedida a quem exercia a função.

\section{ALGUMAS PALAVRAS A GUISA DE CONCLUSÃO}

\section{Ah, professora, sonhe, se possível! (Carta número 8)}

Minha querida amiga:

Fiquei pensando em como terminar estas missivas que te envio com tanto carinho, há vários dias. E talvez o melhor jeito de terminar seja o mais clichê de todos: te pedindo para que não desista, apesar da aridez dos dias. Tempos áridos pedem pessoas macias, que saibam se adaptar a eles, mas que também façam todo o possivel para mudá-lo. Sonhe, se possível for. E sonhe sempre no coletivo, com outros sonhadores. Mas não apenas. Trabalhe todos os dias para que novos tempos venham.

Estamos todos assustados com a barbárie que parece instalada em nosso país e no mundo. Não sabemos direito onde erramos, ou mesmo o que erramos. Ou talvez não seja erro; talvez seja apenas a história e seus (des)caminhos. Mas sabemos que precisamos continuar insistindo em um novo tipo de sociedade. Porque a que temos visto não é mais possivel. Precisaremos de muita persistência nesses dias ruins.

Uma (outra) amiga me disse que já passamos por dias piores, e é verdade. Mas tenho a impressão de que nesses dias ol hávamos e víamos uma perspectiva, uma luz ao final, para onde caminhávamos inexoráveis. Talvez porque éramos muito jovens, talvez. Hoje, disse a ela, tenho a impressão de que caminhamos para trás. A cada dia um novo passo, um novo recuo. E não vemos perspectiva de luz. Parece que as sombras se instauraram definitivamente. Mas, como também aprendemos, nada é definitivo na história. E a isso me agarro e espero que você também. O amanhã nasce do agora, como muita gente iá disse. Então façamos esse futuro. Pelos nossos filhos, nossos alunos, por nós, querida amiga, que iá caminhamos tanto e não merecemos jamais a amargura. Que a possibilidade de doçura esteja em nossas mãos. Nas suas, nas minhas, nas das futuras gerações. Que eles não nos vençam. Porque somos portadores de sonhos.

Termino então te contando uma história. Há mais de 30 anos, minha professora de Sociologia na graduação encerrou um semestre com um fragmento de poema escrito na lousa com giz. Dizia alguma coisa como: "A vós jovens, porque sois belos". Não consegui, apesar de vivermos na era google, a referência. Na minha cabeça, ficou registrado como de Cecília Meireles, mas pode não ser. Duas coisas me veem com essa história. A primeira é que minha memória é péssima pra quase tudo, mas tenho registrado, com a clareza de uma fotografia, um fragmento de poema escrito num quadro negro há mais de 30 anos. Isso diz muito sobre mim. Mas diz também sobre o que é ser professor. Essa minha professora, Léa de Lourdes Calvão, éo ideal de professora que persegui minha vida inteira. Uma professora que consegue 
marcar a vida de um aluno, assim é o que precisamos e merecemos. Ela me ensinou muito, mas, principalmente, a não esmorecer nos dias ruins. É só isso que precisamos. Acreditar e seguir em frente. Espero que também seja assim com você.

Na procura da referência do que acreditei ser de Cecília Meireles, encontrei esse poema que deixo aqui para, finalmente, terminar essas cartas. É um poema duro, que fala do desencanto que a velhice pode nos trazer. Como não quero terminar com esse sentimento de desencanto, transcrevo logo abaixo outro poema que tem me acalentado em dias ruins. Se chama Boa Ossatura, de Maggie Smith. Me despeço de você com eles e com todo meu amor, e meu desejo de que você possa sempre ver a boa ossatura do mundo e nunca perca o encantamento pela vida e pela docência.

Retrato

Cecília Meireles

Eu não tinha este rosto de hoje, Assim

calmo, assim triste, assim Magro.

Nem estes olhos tão vazios, Nem o

lábio amargo.

Eu não tinha estas mãos sem

Força,

Tão paradas e frias e mortas; Eu não tinha este coração que nem Se mostra.

Eu não dei por esta mudança,

Tão simples, tão certa, tão fácil;

-Em que espelho ficou perdida a minha face?

\section{Boa Ossatura}

Maggie Smith

A vida é curta, mas não contarei às crianças. A vida é curta, e encurtei a minha de mil maneiras deliciosas e desaconselhadas mil maneiras deliciosamente desaconselhadas que não contarei às crianças. O mundo é pelo menos cinquenta por cento terrivel, e esta é uma estimativa conservadora, mas não contarei às crianças.

Para cada pássaro há uma pedra arremessada contra um pássaro. Para cada criança amada, uma criança despedaçada, ensacada, afundada em um lago. A vida é curta e pelo menos metade do mundo é terrivel, e para cada gentil estranho, há um que lhe despedaçaria, mas não contei às crianças. Estou tentando vender o mundo a elas. Qualquer corretor de imóveis decente, the apresentando uma verdadeira espelunca gorjeia sobre boa ossatura: este lugar poderia ficar lindo, não é? Você poderia fazer este lugar ficar lindo.

Enfim querida amiga, me despeço, com o desejo de dias melhores, ensolarados e belos como mereceremos! 
Escrever este memorial, apesar do tempo curto e das dúvidas que me atormentaram até o último minuto - se seria possível apresentá-lo realmente ou não -, foi um exercício maravilhoso. A dúvida foi especialmente em relação à reforma da previdência que se avizinha e, tendo completado todos os requisitos para me aposentar, o medo de como os direitos adquiridos serão tratados na proposta de reforma. Fiz o Memorial para concorrer ao cargo de titular sabendo que, a qualquer momento, a proposta de reforma poderia ser apresentada e, como não há nenhuma certeza sobre os encaminhamentos propostos, sabia que, caso isso acontecesse, teria que abandonar o desejo de ser titular e encaminhar o processo de aposentadoria.

Revisitei minha história, coisa que sempre gosto de fazer. Assumi, talvez de forma um tanto presunçosa (percebo ao reler o que fiz), a postura de narradora, tal como denominado por Walter Benjamin. Talvez eu saiba ainda muito pouco. Talvez 35 anos de docência nem seja tanta coisa assim. É nisto que penso agora ao concluir: que talvez nada do que disse aqui tenha importância para outras pessoas. Mas aí me lembro de que é um Memorial, cuja função é exatamente esta: marcar memórias, o que teve importância para você.

Nessa aventura com aspectos de uma "escrita de si", foi possível perceber duas coisas sobre mim e, talvez, concluir que minha história não é tão única assim. É a história de dezenas de outras professoras, com percalços e encantos. A primeira delas é que minha história pessoal está entrelaçada à minha trajetória acadêmica e profissional de forma tão imbricada, que, em alguns momentos, não consigo falar de uma sem me referir a outra. As grandes marcas pessoais que tive na vida (a morte prematura do meu primeiro companheiro, o nascimento do meu filho, a separação do meu segundo marido e, algo de que não falei aqui, mas uma experiência muito forte com minha saúde em 2015) foram guiando-me para decisões que impactaram minha vida profissional. Como acredito que somos seres indissolúveis, vejo isso como algo que não poderia ser diferente. A outra coisa que percebo é que o trabalho foi algo fulcral em minha vida e, especialmente, o trabalho na UFMS. Foi como professora nesta universidade 
que construí minha vida material, minhas referências e, especialmente, grande parte dos meus amigos. Ou seja: a UFMS, nesses 26 anos de história, me deu quase tudo que construí. Sempre quis terminar minha carreira com uma sensação de que estávamos, a UFMS e eu, totalmente plenas uma com a outra, sem o sentimento de dever algo a ela ou ela a mim. E é assim que encerro. Trabalhei muito nesses 26 anos de universidade e fui recompensada por isso. Não devemos nada uma à outra. Minha carreira foi construída de forma reta e tenho orgulho dela. Nunca precisei abrir mão dos meus princípios para me encaixar em qualquer lugar que fosse. Em tempos como o nosso, isso não é pouca coisa.

Ao concluir, percebo mais outra questão. Atuei em várias frentes. Fui professora da pós-graduação, orientei trabalhos, participei de bancas, emitindo opinião sobre o trabalho de outros. Pesquisei, fiz extensão e escrevi. Proferi palestras, ministrei cursos e oficinas em muitas ocasiões. Coordenei grupos de pesquisa e grupos em entidades científicas. Gostei de todas elas. Mas a única que tenho certeza de que fiz bem e onde fui mais feliz foi como professora da graduação e, especialmente, como professora do primeiro ano do curso de Pedagogia. O encanto dos alunos com cada novidade descoberta, o jeito como consigo aproximar-me deles, o rigor que tenho, mas que, logo em seguida ao começo das aulas, é entendido como um traço de respeito e preocupação com eles, tudo isso me faz ter essa certeza. Fui uma boa professora de graduação. Nas outras coisas todas que fiz, sempre dei o melhor de mim, não tenho dúvida. Tentei fazer tudo do melhor jeito que era possível com as condições que tinha. Mas, em nenhuma delas, tenho a certeza que tenho em relação à docência, especialmente na graduação.

Termino então com a sensação de plenitude. Concorro à cadeira de titular para, logo em seguida, pedir minha aposentadoria, se der tempo. Se fossem outros tempos, talvez não fizesse isso. Estou jovem e sinto que talvez esteja no melhor momento do meu trabalho, apesar dos traços de desesperança que insistem em rondar-me. A tragédia anunciada para o país e, especialmente, para a educação pública e, mais especialmente ainda, para as universidades públicas começa a concretizar-se. Isso me obriga a sair e, como já disse, espero que tenha tempo. Porque vivemos uma época em que ninguém sabe o que acontecerá. Espero sair da UFMS, mas tenho certeza de que não irei me retirar 
da luta. Que seja entregando panfleto em praça pública como preconizei um dia com meus companheiros de sindicato. Que seja escrevendo para falar das atrocidades que certamente virão. De alguma forma, encontrarei um jeito de continuar na resistência".

\section{REFERÊNCIAS BIBLIOGRÁFICAS}

LAHIRE, B. Culture écrite et einegalités scolaires. Lyon: Presses Universitaires, 1993.

MUHANA, A. O gênero epistolar: diálogo per absentiam. Discurso, (31), 329346, 2000. https://doi.org/10.11606/issn.2318-8863.discurso.2000.38043.

NOGUEIRA, M. A. NOGUEIRA, C. A sociologia da Educação de Pierre Bourdieu: limites e contribuições. Educação e Sociedade. Vol. 23, n. 78, p. 15-35, 2002.

ROMANELLI, G. Família de camadas médias e escolarização superior dos filhos: O estudante trabalhador. NOGUEIRA, M. A.; ROMANELLI, G.; ZAGO, N. (org.). Família e escola: trajetórias de escolarização em famílias de camadas populares e médias. 4. ed. Petrópolis: Vozes, 2008.

VIANA, M. J. B. Longevidade escolar em famílias de camadas populares: algumas condições de possibilidade. In: NOGUEIRA, M. A.; ROMANELLI, G.; ZAGO, N. (org.). Família e escola: trajetórias de escolarização em famílias de camadas populares e médias. 4. ed. Petrópolis: Vozes, 2008.

ZAGO, N. Processos de escolarização nos meios populares: As contradições da obrigatoriedade escolar. In: NOGUEIRA, M. A.; ROMANELLI, G.; ZAGO, N. (org.). Família e escola: trajetórias de escolarização em famílias de camadas populares e médias. 4. ed. Petrópolis: Vozes, 2008. 